$1-1-2014$

\title{
Neutral Litigants in Patent Cases
}

Jeremy W. Bock

Follow this and additional works at: http://scholarship.law.unc.edu/ncjolt

Part of the Law Commons

\section{Recommended Citation}

Jeremy W. Bock, Neutral Litigants in Patent Cases, 15 N.C. J.L. \& Tech. 233 (2014).

Available at: http://scholarship.law.unc.edu/ncjolt/vol15/iss2/3

This Article is brought to you for free and open access by Carolina Law Scholarship Repository. It has been accepted for inclusion in North Carolina Journal of Law \& Technology by an authorized administrator of Carolina Law Scholarship Repository. For more information, please contact law_repository@unc.edu. 


\section{NORTH CAROLINA JOURNAL OF LAW \& TECHNOLOGY \\ VOLUME 15, ISSUE 2: JANUARY 2014}

\section{Neutral Litigants in Patent Cases*}

\section{Jeremy W. Bock ${ }^{* *}$}

Patent cases at the district court level are one of the most complex, time-consuming, and contentious forms of civil litigation. As an alternative to the conventional, two-sided adversarial process, this Article proposes a structural change to the manner of conducting patent litigation in the district courts: the addition of a neutral litigant who, as the "third" side, represents the public interest and participates alongside the parties in all aspects of the case. Based on a novel game theoretic model, along with lessons from the International Trade Commission and the Solicitor General's amicus practice before the Supreme Court, the presence of the neutral litigant is expected to decrease the overall level of contentiousness so as to improve the district court's ability to adjudicate complex issues in a manner that both advances the development of the law, and serves the public interest in the fair, accurate, timely, and efficient resolution of patent disputes.

* (C) 2014 Jeremy W. Bock

** Assistant Professor of Law, The University of Memphis, Cecil C. Humphreys School of Law. The Author thanks Aditi Bagchi, Robert Barr, Jamison Colburn, Stephen Ellmann, John Golden, Parisa Jorjani, Megan La Belle, Mark Lemley, James Lindgren, Brian Love, Evelyn Mak, Peter Menell, Janice Nadler, Mary Beth O'Connor, Gabriella Raymond, Greg Reilly, David Schwartz, Suzanne Scotchmer, David Sklansky, James Speta, Andrew Thomases, Michelle Yang, James Yoon, and the participants at the 2012 Intellectual Property Scholars Conference at Stanford Law School and the 2013 Works-in-Progress in Intellectual Property at Seton Hall University School of Law for helpful discussions and feedback. 


\section{TABLE OF CONTENTS}

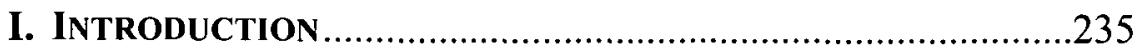

II. SOURCES OF UNNECESSARY CONTENTIOUSNESS ................242

III. Litigation Dynamics With a NeUtral Litigant ........249

A. Lessons from the ITC and the Solicitor General ...........250

B. Essential Characteristics and Effects ...........................258

C. The Neutral Litigant and Discovery: A Game Theoretic

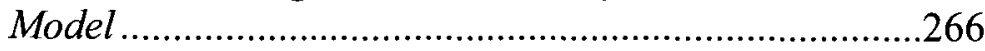

IV. Mechanism for NeUtral Litigant Participation ....282

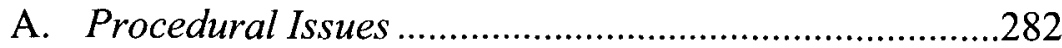

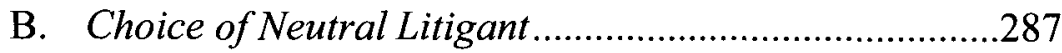

C. Case Selection and Cost ...............................................2296

V. General ObJeCtions ANd ConCERnS ...............................301

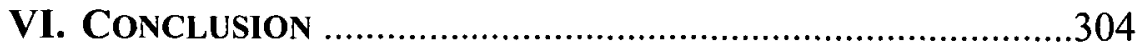




\section{INTRODUCTION}

In every patent case, the public has an interest ${ }^{1}$ in the fair, accurate, efficient, and just resolution of the dispute in a manner that strikes the proper balance among the interests of the patentee, the accused infringer, and the public at large. ${ }^{2}$ The academic literature in the patent field is replete with advice to courts on how to apply ${ }^{3}$ or modify ${ }^{4}$ various rules and doctrines, so as to avoid results contrary to the public interest. However, patent scholars

${ }^{1}$ See, e.g., Precision Instrument Mfg. Co. v. Auto. Maint. Mach. Co., 324 U.S. 806,816 (1945) ("A patent by its very nature is affected with a public interest.").

${ }^{2}$ See, e.g., Pfaff v. Wells Elecs., Inc., 525 U.S. 55, 63 (1998) ("The balance between the interest in motivating innovation and enlightenment by rewarding invention with patent protection on the one hand, and the interest in avoiding monopolies that unnecessarily stifle competition on the other, has been a feature of the federal patent laws since their inception.").

${ }^{3}$ See, e.g., Mark A. Lemley, Software Patents and the Return of Functional Claiming (Stanford Pub. Law Working Paper No. 2117302, 2012), available at http://ssrn.com/abstract $=2117302$ (arguing for rigorous application of rules associated with means-plus-function claims); Chester S. Chuang, Unjust Patents \& Bargaining Breakdown: When Is Declaratory Relief Needed?, 64 SMU L. REV. 895 (2011) (outlining policy considerations for district courts when exercising jurisdiction under the Declaratory Judgment Act); Janice M. Mueller \& Donald S. Chisum, Enabling Patent Law's Inherent Anticipation Doctrine, 45 Hous. L. Rev. 1101, 1103 (2008) ("In this Article we argue that the inherent anticipation doctrine should be narrowly and sparingly applied."); Dan L. Burk \& Mark A. Lemley, Policy Levers in Patent Law, 89 VA. L. REV. 1575, 1668 (2003) (encouraging courts to use various "policy levers" to "tailor the general legal standards of patent law to the needs of particular industries").

${ }^{4}$ See, e.g., Brian J. Love, Interring the Pioneer Invention Doctrine, 90 N.C. L. REV. 379, 384 (2012) ("[W]hile the pioneer doctrine remains among the living, this Article argues that it should now be interred once and for all."); Christopher B. Seaman, Reconsidering the Georgia-Pacific Standard for Reasonable Royalty Patent Damages, 2010 BYU L. REV. 1661, 1711 ("In lieu of Georgia-Pacific, this Article proposes that courts should adopt an alternative standard for imposing a reasonable royalty. ....); John M. Golden, Construing Patent Claims According to Their "Interpretive Community": A Call for an Attorney-Plus-Artisan Perspective, 21 HARV. J.L. \& TECH. 321, 328 (2008) (arguing that courts should "replac[e] the ordinary artisan rule with a rule declaring the governing perspective of claim construction to be a hybrid one: the perspective of a patent attorney with access to the technological knowledge of an ordinary artisan"). 
have paid scant attention to the docket management pressures ${ }^{5}$ faced by district judges, which, separate and apart from any particular rule or doctrine, may also affect case outcomes by influencing the timing and manner of adjudication. Docket management concerns are especially acute in patent litigation, as it is one of the most contentious forms of civil litigation at the district court level: ${ }^{6}$ It is the only form of complex civil litigation for which no less than twenty federal judicial districts have found it necessary to adopt specialized "patent local rules" governing the

${ }^{5}$ A significant constraint on a district court's docket is the Speedy Trial Act, 18 U.S.C. $\S \S 3161-3174$ (2006), which imposes timing requirements in criminal cases. Cf. Kent Sinclair \& Patrick Hanes, Summary Judgment: A Proposal for Procedural Reform in the Core Motion Context, 36 WM. \& MARY L. REV. 1633, 1672 (1995) ("[B]usy courts, particularly those of the federal system-in which the demands of the criminal case docket under the Speedy Trial Act are such that most working days are devoted to criminal, not civil, cases- . . feel[ ] that they have literally 'no time to waste' on motions that may not directly resolve the civil case.").

${ }^{6}$ See, e.g., Victor G. Savikas, Survey Lets Judges Render Some Opinions about the Patent Bar, NAT'L L. J., Jan. 18, 1993, at 58 (reporting results of survey with responses from 256 district judges where "[t]hirty-eight percent of the respondents said that discovery disputes are more prevalent in patent cases than in other types of civil litigation").

The contentious nature of patent disputes has not gone unnoticed by the Federal Circuit. "The Rambo Litigator" was the subject of the first panel in the first plenary session at the Federal Circuit's 1993 Judicial Conference, where the late Helen Nies, a former Chief Judge of the Federal Circuit, observed:

In hardball litigation, every request by the other side is opposed with paper, with briefs, and requests for argument, even a request for a two day extension of time. Discovery requests are made deliberately ambiguous and sweeping and no matter what reply is made, there's a charge of non-compliance. Depositions are scheduled at inconvenient times and mail is sent by slow boat to shorten the other side's time to respond. At depositions, there are senseless objections, bickering and delay and depositions are endless in numbers, whether there's anything under the next stone or not. Many stones do not have to be turned over. If a minor motion is lost, there's a demand for sanctions for a frivolous pleading.

The Tenth Annual Judicial Conference of the United States Court of Appeals for the Federal Circuit, 146 F.R.D. 205, 217 (1993).

${ }^{7}$ A list of the federal judicial districts that have adopted patent local rules as of 2012, as well as examples of patent local rules from select districts, are 
content and timing of disclosures in an attempt to make patent cases more manageable. ${ }^{8}$

In patent litigation, the parties are often too willing to fight without regard to the relative importance of an issue or the strength of the other side's position, ${ }^{9}$ such that protracted discovery disputes ${ }^{10}$ and high-volume, overly-aggressive motion practice ${ }^{11}$ are common. By multiplying the number of issues requiring the court's attention and presenting highly-polarized arguments that provide an incomplete, heavily-skewed analysis of the facts and the law, parties that engage in overly contentious advocacy complicate the court's already difficult task of adjudicating issues that are complex both legally and technically. ${ }^{12}$ Indeed, it is not

available in Peter S. Menell, Lynn H. Pasahow, James Pooley, Matthew D. Powers, Steven C. Carlson, \& Jeffrey G. Homrig, Fed. Judicial Ctr., Patent Case Management Judicial Guide Appendix D (2d ed. 2012), available at $\mathrm{http}: / / \mathrm{ssrn} . \mathrm{com} / \mathrm{abstract}=2114398$.

${ }^{8}$ See, e.g., Jessie Seyfer, Patent Judges Buried in Paper, THE ReCORDER (Mar. 5, 2007) ("The Northern District [of California] has actually tried to head off needless quibbling and confusion for years with its local patent rules .... The rules set clear timelines for discovery and force each side to state clearly and early what kind of evidence they want the other side to produce."). However, the patent local rules themselves have become a source of litigation. $I d$. ("These rules have helped, judges say, but[,] as often happens with rules[,] they've also given attorneys more to fight over.").

${ }^{9}$ See, e.g., Seyfer, supra note 8 ("'The patent bar tends to fight,' said Magistrate Judge Edward Chen. 'They tend to be . . . quite litigious, maybe because of the dollars involved. You don't have the limits of the economics of the case that would typically apply to other civil litigation."').

${ }^{10}$ See, e.g., William T. Gallagher, IP Legal Ethics in the Everyday Practice of Law: An Empirical Perspective on Patent Litigators, 10 J. MarShall REv. INTELL. PROP. L. 309, 324 (2011) (noting that almost all patent litigators who were surveyed considered "discovery practice in patent cases to be 'a big game,' ... by opposing counsel who seek to prolong discovery battles in an attempt to wear down the other side or sometimes even get opponents to give up trying to get certain information due to the extraordinary costs of discovery disputes").

"See, e.g., Seyfer, supra note 8 (" "If either party becomes contentious, the other party needs to respond to that,' said Fish \& Richardson partner Katherine Lutton, head of her firm's litigation practice. 'If one side files a 40-page brief that shoots from the hip, you need to respond to the arguments in it.' ").

12 Kathleen M. O'Malley, Patti Saris \& Ronald M. Whyte, A Panel Discussion: Claim Construction from the Perspective of the District Judge, 54 CASE W. RES. L. REV. 671, 682 (2004) (statement of Judge Patti Saris) ("Patent 
uncommon for district judges to be led astray by counsel. ${ }^{13}$ In short, unnecessary contentiousness adversely affects the ability of district courts "to secure the just, speedy, and inexpensive determination of every action and proceeding."14

At the same time, the high cost of contentious litigation may prompt some parties to settle prematurely rather than pursue meritorious positions that may help establish the proper scope of patent rights ${ }^{15}$ and contribute to the evolution of case law. ${ }^{16}$ Indeed, the business model of collecting nuisance-value settlements that is commonly practiced by so-called "patent trolls" is made viable in large part by the notoriously expensive nature of patent litigation. ${ }^{17}$

Accordingly, this Article sets forth a proposal for dampening the high level of contentiousness in district court patent cases in order to improve the speed and accuracy of adjudication, as well as to enhance the ability of the trial court to decide issues in a manner

litigation is like the neurosurgery of litigation: it is hard scientifically and it is hard legally.").

${ }^{13}$ See, e.g., Practitioners and Jurists Exchange Views On Patent Litigation at Sedona Conference, 65 P.T.C.J. 52 (2002) ("A federal trial judge at the conference blamed the lawyers in part for not explaining the difficult science involved in patent cases and for failing to minimize the issues at trial. ' $\mathrm{I}$ 'm getting half truths from you,' she charged. 'You know you can trip me up and get me flipped on appeal,' she added.").

${ }^{14}$ FED. R. CIV. P. 1.

${ }^{15}$ See Megan M. La Belle, Against Settlement of (Some) Patent Cases (Apr. 17, 2013) 67 VAND. L. REV. (forthcoming 2014) (manuscript at 5), available at http://ssrn.com/abstract=2252849 (arguing that "adjudication of certain types of patent cases will promote the public good by eradicating invalid patents").

${ }^{16}$ For example, the calculation of damages in patent disputes is one area where case law development is critically needed. See Stanford Law School, Patent Institutions Summit: The Federal Circuit/District Court Interface, YouTuBE (May 21, 2012), http://www.youtube.com/watch? $\mathrm{v}=$ ni9NZo5yWpM at 1:10:25-1:11:46. The Federal Circuit has signaled a willingness to look at this matter, provided there are suitable cases from the district courts that tee-up the issues for appellate review. See id.

${ }^{17}$ In 2011, the median cost of patent litigation for cases having: (i) less than $\$ 1$ million at risk was $\$ 650,000$; (ii) $\$ 1-\$ 25$ million at risk was $\$ 2.5$ million; and (iii) more than $\$ 25$ million at risk was $\$ 5$ million. LAW PRACTICE MGMT. COMm., Am. InTEllectual Prop. LAW Ass'N., Report of The ECONOMIC SURVEY 35 (2011). 
that may help advance the law in a direction that promotes the public interest. Specifically, this Article proposes adding a third litigant - in addition to the patentee and the accused infringer - to district court patent cases: a neutral third party charged with representing the public interest. This "neutral litigant" would substantively participate in all major aspects of the case, including discovery and motion practice, and perhaps even trial and settlement, and would take positions based on an impartial analysis of the facts and the law that is informed by public interest considerations. Notably, the dampening of the parties' tendency to be contentious is expected to occur indirectly as a collateral effect of the neutral litigant's participation in the case. That is, the neutral litigant's presence exerts a moderating influence even though its purpose is not to police the behavior of the parties, but rather to participate in the litigation alongside them as a non-partisan (i.e., having neither a pro- nor anti-patentee agenda) representative of the public interest.

Because the neutral litigant's positions on any given issue will be based on a disinterested analysis, its views are likely to be accorded substantial weight by the judge. As a result, each of the opposing parties - the patentee and the accused infringer-may find it necessary as a matter of strategy to pick its battles and take less extreme positions in order to either gain the neutral litigant's support on an issue or make its position appear more credible to the court when it is opposed by the neutral litigant. ${ }^{18}$ In this manner, the presence of the neutral litigant is expected to alter the litigation dynamics between the parties so as to disincentivize the pursuit of unreasonable positions that engender unnecessary contentiousness.

To be clear, the neutral litigant's presence is not expected to eliminate all contentious behavior. Rather, the level of contentiousness in the case is expected to be lower with the neutral litigant than it otherwise would be. Decreasing the overall level of contentiousness in a case may help streamline the number and variety of issues requiring the court's attention and enhance the analytical quality of the briefing. This would improve the district

\footnotetext{
${ }^{18}$ See infra Part III.B.
} 
court's ability to adjudicate complex patent disputes fairly, with greater accuracy and efficiency, and in a manner that advances the development of the law in furtherance of the public interest.

In a highly-complex, hotly-contested patent dispute, the introduction of an additional litigant may appear to be a counterintuitive means of decreasing the overall level of contentiousness. However, this comports with the experiences of the attorneys who litigate patent disputes at the International Trade Commission ("ITC"), where a staff attorney from the ITC's Office of Unfair Import Investigations ("OUII") serves in a capacity similar to the neutral litigant proposed in this Article. ${ }^{19}$ Notably, the beneficial dynamic of a three-sided litigation environment with a neutral litigant is not endemic to ITC actions. Indeed, it has also been observed at the appellate level-particularly in the context of the Solicitor General's amicus practice before the Supreme Court, where the Solicitor General's participation induces the petitioner and the respondent to streamline their arguments. ${ }^{20}$ As such, the neutral litigant proposal may be generally applicable to a variety of district court cases as a way of decreasing the overall level of contentiousness and to allow the public interest to be represented as a standalone entity. For illustrative purposes, however, this Article focuses on patent cases because the proposal itself is modeled after the three-sided patent litigation dynamic at the ITC. Although the staff attorneys at the ITC have been involved in patent-related actions since the $1970 \mathrm{~s},{ }^{21}$ their role in creating a litigation dynamic that is different from that of the district courts ${ }^{22}$ has largely escaped detailed scholarly analysis. This Article fills that gap by providing a novel, game theoretic model ${ }^{23}$ of the

${ }^{19}$ See infra Part III.A.

${ }^{20}$ See infra Part III.A.

${ }^{21}$ The first Section 337 investigation that involved a staff attorney from the OUII (or its predecessor) was Inv. No. 337-TA-001, In the Matter of Certain Electronic Pianos, which was instituted in 1972 and terminated in 1976 . OUII 337 Investigative History, OFFICE OF UNFAIR IMPORT INVESTIGATIONS (last visited Nov. 9, 2013), http://info.usitc.gov/ouii/public/337inv.nsf/56ff5fbca 63b069e852565460078c0ae/e725af860b5f4b228525661300746298?OpenDocu ment.

${ }^{22}$ See infra Part III.A.

${ }^{23}$ See infra Part III.C. 
dynamics of a district court patent case with a neutral litigant who represents the public interest, as well as laying out a blueprint for including such a litigant in current patent cases. ${ }^{24}$

To be clear, this Article is not calling for the end of zealous advocacy or the adversarial system. Rather, the problem this Article addresses is a style of litigation characterized by unnecessary contentiousness that goes beyond ethical zealous advocacy. Unfortunately, for many patent litigators, there is no "zealous" advocacy other than the overzealous variety. ${ }^{25}$ Indeed, the "duty" justifying and excusing scorched-earth litigation tactics. ${ }^{27}$

This Article proceeds as follows: Part II explores the factors that enable unnecessary contentiousness to flourish in district court patent litigation. Part III lays out the essential characteristics of the neutral litigant based on lessons from the ITC as well as the Solicitor General's amicus practice before the Supreme Court. It then develops a game theoretic model of how the neutral litigant's presence may change the litigation dynamics of a case to induce the parties to adopt a less contentious litigation strategy. Part IV analyzes the procedural mechanisms for including a neutral litigant in a case, evaluates the suitability of various entities to serve as a neutral litigant, and discusses the types of cases for which neutral litigant participation may be appropriate. Part V addresses certain general objections and concerns regarding the use of a neutral litigant, and is followed by a brief Conclusion in Part VI.

${ }^{24}$ See infra Part IV.

${ }^{25}$ Cf. Gallagher, supra note 10, at 324 ("[T] expressed a firm conviction that ethical lawyering is primarily concerned with zealously advancing the client's interests, rather than a broader notion of a lawyer's ethical duties to the legal system . . . or even to the concern for a 'just' resolution in a case.").

${ }^{26}$ See Model Rules of Prof'L CONDuCt R. $1.3 \mathrm{cmt}$. (1983) ("A lawyer must . . . act with commitment and dedication to the interests of the client and with zeal in advocacy upon the client's behalf.").

${ }^{27}$ See, e.g., Paul C. Saunders, Whatever Happened To "Zealous Advocacy"?, 245 N.Y. L.J. (Mar. 11, 2011) (noting Illinois Circuit Judge Richard Curry's observation that "'Zealous advocacy' is the buzz-word which serves to legitimize the most outrageous conduct, conduct which regrettably debases the profession as well as the perpetrator" (citation omitted)). 


\section{SOURCES OF UNNECESSARY CONTENTIOUSNESS}

To better conceptualize how a neutral litigant could help decrease the overall level of contentiousness in a patent case, it may be useful to first consider the circumstances and influences that may facilitate or promote it.

The conventional tools courts use to impose behavioral norms-namely, rules and sanctions-are, by themselves, inadequate to change the litigation dynamics that give rise to hardball tactics. The Federal Rules, as well as the Patent Local Rules, ${ }^{28}$ vest considerable discretion with the court in the management of individual cases. ${ }^{29}$ Unfortunately, by leaving room for discretion, ${ }^{30}$ the rules invite litigation. And if the stakes are high enough, even rules that are arguably highly specific in their requirements ${ }^{31}$ - and are generally not amenable to discretionary application-may also engender litigation. Accordingly, the

28 See, e.g., N.D. CAL. PAT. L.R. (Dec. 1, 2009), available at http://www.cand.uscourts.gov/localrules/patent.

${ }^{29}$ See, e.g., Robert G. Bone, Who Decides? A Critical Look at Procedural Discretion, 28 CARDOZO L. REV. 1961, 1967-68 (2007) ("Case-specific discretion has been at the heart of the Federal Rules ever since they were first adopted in 1938. There are two main ways discretion operates: a Federal Rule might delegate discretion explicitly, or it might facilitate discretion indirectly by using intentionally vague language that invites flexible interpretation."); N.D. CAL. PAT. L.R. 1-3 (Dec. 1, 2009) ("The Court may modify the obligations or deadlines set forth in these Patent Local Rules based on the circumstances of any particular case. ...").

${ }^{30}$ Discretion is often built into the rules through the use of terms, such as "good cause" or "reasonable," that signal the need for a case-by-case analysis by the court, and which leave room for differences of opinion between opposing parties. In the Federal Rules of Civil Procedure, for example, the term "good cause" appears in approximately two dozen places, while "reasonable" and its variants appear in almost ninety places.

${ }^{31}$ One of the more specific rules in the N.D. Cal. Patent L.R. governs the disclosure of infringement contentions. N.D. CAL. PAT. L.R. 3-1 (Dec. 1, 2009). The sufficiency of the patentee's compliance with this Rule, however, is often hotly-contested. See Seyfer, supra note 8 ("[The Patent Local] rules have helped, judges say, but, as often happens with rules, they've also given attorneys more to fight over. For instance, now people dispute whether a side followed the rules well enough. 'You get disputes of whether there was an adequate amount of disclosure ....", ). 
introduction of new or modified rules, without more, may be of limited effectiveness in controlling the level of contentiousness. ${ }^{32}$

Likewise, the availability of sanctions ${ }^{33}$ has not deterred parties from engaging in discovery misbehavior or taking untenable positions before the court. This is because courts impose sanctions rather sparingly, ${ }^{34}$ which leads the parties and their attorneys to heavily discount them..$^{35}$ That sanctions are reserved for only the most egregious cases may be indicative of the court's limited ability to reliably detect abuse and craft an appropriate sanction. ${ }^{36}$ In addition, the rarity of sanctions may also reflect the court's desire to discourage parties from filing unmeritorious sanctions motions as a litigation tactic. ${ }^{37}$

${ }^{32}$ See, e.g., Interim Report of the Committee on Civility of the Seventh Federal Judicial Circuit, 143 F.R.D. 371, 406 (1991) [hereinafter Interim Report] ("[J]udges and lawyers do not favor more rules or regulations to handle civility problems, since they are perceived to be a major factor contributing to the decline in litigation courtesy.").

${ }^{33}$ See, e.g., FED. R. CIV. P. 11 (sanctions for pleading and motion abuses); FED. R. CIV. P. 16(f) (sanctions for failure to obey pretrial orders), FED. R. CIV. P. 37 (sanctions for discovery violations); see also 28 U.S.C. $\$ 1927$ (2006) (sanctions for vexatious multiplication of proceedings); 18 U.S.C. $\S 401$ (2006) (court's contempt power).

${ }^{34}$ See Gallagher, supra note 10 , at 341 ("A common response from [the] litigators was that sanctions were so rare they were not considered a credible threat.").

${ }^{35}$ See E. Donald Elliott, Managerial Judging and the Evolution of Procedure, 53 U. CHI. L. REV. 306, 313 (1986) ("[T] he 'present value' of sanctions will be discounted depending on how likely an attorney believes it to be that a judge will actually impose sanctions.").

${ }^{36}$ See Bone, supra note 29, at 2009. Cf. William W. Schwarzer, The Federal Rules, The Adversary Process, and Discovery Reform, 50 U. PITT. L. REV. 703, 711 (1989) ("It is no answer to say that these [litigation] abuses can be discouraged and controlled by sanctions. The imposition of sanctions is itself a vagarious, costly, and time-consuming process that aggravates relations among the parties and the court and rarely undoes the damage done.").

See Byron C. Keeling, A Prescription for Healing the Crisis in Professionalism: Shifting the Burden of Enforcing Professional Standards of Conduct, 25 TEX. TECH L. REV. 31, 47 (1993) ("Hardly cowed by the threat of judicial sanctions, hardball litigators have learned to use sanctions provisions affirmatively. For example, hardball litigators practicing in federal court have learned to deflect attention from their own actions with repeated motions for Rule 11 sanctions against opposing counsel."). 
Furthermore, rules and sanctions are essentially "spot treatments" that are invoked and applied episodically, whereas hyper-contentiousness generally pervades the case as a whole, assuming several forms and affecting a range of issues. The various forms of unnecessary contentiousness may include: protracted discovery battles; ${ }^{38}$ voluminous motion practice $;^{39}$ inaccurate or incomplete characterizations of the facts or the law; ${ }^{40}$ and incivility. ${ }^{41}$ In patent litigation, almost every issue in the case is the subject of highly-contentious advocacy, ${ }^{42}$ where the parties often take overly-aggressive, highly-polarized positions that largely eschew any middle ground, whether it pertains to procedural matters (e.g., scheduling issues, requirements under the Patent Local Rules, discovery disputes) ${ }^{43}$ or the merits (e.g., claim construction, patent liability issues, remedies). ${ }^{44}$ In short, contentiousness is reflected in both the manner of litigation as well as the substance of the parties' theories and arguments across a variety of issues.

That unnecessary contentiousness within a patent case tends to be systemic in nature suggests that potential solutions may require

${ }^{38}$ See supra note 10 and accompanying text.

${ }^{39}$ Robert N. Sayler, Rambo Litigation: Why Hardball Tactics Don't Work, 74 A.B.A. J. 78 (Mar. 1988) (observing that one of the characteristics of hardball lawyering is "[a] hair-trigger willingness to fire off unnecessary motions").

${ }^{40}$ Marc R. Lieberman \& Richard K. Mahrle, Learned Hand for A Day: The Rewards of Division One's Pro Tem Program, 33 AZ ATT'Y 37, 39 (June 1997) (noting that "hardball litigation tactics lawyers hold so dear [include] for example, conveniently failing to address key issues and authorities, misconstruing record references").

${ }^{41}$ Michael Asimow, Embodiment of Evil: Law Firms in the Movies, 48 UCLA L. REV. 1339, 1387 (2001) ("One very prevalent hardball tactic is incivilitythat is, rude, bullying behavior that is designed to intimidate other lawyers or witnesses.").

${ }^{42}$ See Seyfer, supra note 8 ("Attorneys [in patent cases], in their zeal to protect clients in foggy legal territory, can fight tooth and nail over jusc about everything.").

${ }^{43}$ See, e.g., id. (" 'You get disputes of whether there was an adequate amount of disclosure [under the Patent Local Rules], and we fight over that,' [Magistrate] Judge [Edward] Chen said.").

${ }^{44}$ See, e.g., id. ("At claims construction hearings, where the court interprets the patent language in dispute, litigators can sometimes be at their most aggressive, judges say, arguing vehemently about the thinnest shades of meanings of a patent's terms."). 
changing the dynamics within the environment of the case as a whole. Apart from the judge and the applicable rules and case law governing the action, the litigation environment within a case may be shaped substantially by certain behavioral and situational factors affecting the parties, and in particular, their attorneys. ${ }^{45}$ As recognized in the academic literature, high levels of contentiousness may be fueled by attorney self-interest, ${ }^{46}$ namely, the desire for profit ${ }^{47}$ and victory. ${ }^{48}$ Within a law firm, financial considerations coupled with the "will to win" may suppress or discourage more moderate views ${ }^{49}$ regarding litigation strategy, especially where the matter is a high-profile, "bet the company"

${ }^{45}$ See Deborah L. Rhode, Ethical Perspectives on Legal Practice, 37 STAN. L. REV. 589, 635 (1985) ("[P]aper churning and procedural shadow-boxing [by attorneys] suggests a more subtle mixture of adversarial psychology, financial incentives, and perfectionist anxieties.").

${ }^{46}$ Roger C. Cramton, Furthering Justice by Improving the Adversary System and Making Lawyers More Accountable, 70 FordhAM L. REV. 1599, 1608 (2002) ("Hyper-adversarialism prevails in high-stakes cases . . . because it serves the pocket books and egos of lawyers.").

47 Rhode, supra note 45 , at 635 ("As innumerable commentators have noted ... profit dynamics are a major cause of procedural incivilities. . . [M]ost lawyers will prefer to leave no stone unturned, provided, of course, they can charge by the stone. For an attorney anxious to avoid overlooking details and underbilling hours, more is always better.").

48 See Schwarzer, supra note 36, at 710 ("Lawyers' behavior in litigation tends to be dominated by a 'will to win.' Effective and persuasive presentation of the case has little significance to lawyers independent of winning the case ...."); Rhode, supra note 45, at 635 ("As the level of dispute escalates, attorneys' own desires for retribution, if not victory, may skew their decisionmaking.").

${ }^{49} \mathrm{Cf}$., Gallagher, supra note 10, at 328 ("[A]lmost all of the interviewed lawyers were adamant that the grinding need in their firm to meet substantial billable hours requirements left them little time or ability to spend much time or intellectual energy worrying about ethics."); Rhode, supra note 45, at 634 ("By choice or necessity, many lawyers with noncompetitive orientations or strong commitments to family or nonprofit pursuits drift out of firm hierarchies, leaving management composed largely of those who accept revenue-maximizing priorities."). 
case--patent litigation being a prime example ${ }^{50}$-for which the client may be less cost-sensitive. ${ }^{\text {st }}$

At the same time, the client's ability to monitor and counteract his attorney's tendency to over-litigate may be impaired by the client's relatively limited resources and/or expertise compared to that of his attorney, as well as the information asymmetry introduced by protective orders that may prevent the client from having access to any confidential information produced by the opposing party during discovery. ${ }^{52}$ As a result, in large, complex cases, such as patent litigation, the client might rely heavily on his attorney's characterizations of the relative strength or weakness of the case, which may be colored by the attorney's self-interest. In some instances, however, the client may drive the decision to be contentious, especially when responding to discovery requests. In such cases, the attorney will likely stonewall the opposing party rather than press his client to comply with a discovery requestand risk alienating that client while appearing weak to the other side. $^{53}$

Indeed, attorneys who engage in hardball tactics often perceive a need to cultivate a reputation for being tough both as a matter of strategy and to attract clients. ${ }^{54}$ If, however, the opposing attorneys

${ }^{50}$ See John O. Cunningham, Boston Legal Community Sees Bright Future, MASS. LAWYERS WEEKLY, Apr. 18, 2005 ("[T]he most sophisticated legal matters relevant to the largest clients and the 'bet-the-company' matters, such as patent litigation, will face little or no pricing pressure.").

${ }^{51}$ See id.; see also Seyfer, supra note 8 (" '[Patent] cases tend to be very, very important to the clients and involve lots of money,' said U.S. District Judge Ronald Whyte. 'So there's perhaps more reluctance to leave any stone unturned." ").

${ }^{52}$ See Elliott, supra note 35 , at 330-31 ("[I]t is unlikely that clients can accurately assess whether the benefits to the client of additional pretrial preparation exceed the costs. In-house lawyers generally lack the familiarity with the details of litigation strategy that would be necessary to second-guess the recommendations of outside counsel." (emphasis in original)).

${ }^{53}$ See Gallagher, supra note 10, at 338-39.

${ }^{54}$ See Peter M. Appleton, Is Winning Everything?: 'Professionalism' Doesn't Have To Mean 'Doormat,' 62 OR. ST. B. BULL. 21 (2002) ("Litigators with large well-respected Los Angeles firms agree that firms trade on their reputations as hardball litigators. In short, lawyers play hardball because, contrary to what we read, they and their clients believe that hardball works."). 
practice in a limited geographic area-such that they may encounter each other repeatedly in different cases - then having a reputation for being overly aggressive could be professionally disadvantageous. ${ }^{55}$ Unfortunately, this is not the case in patent litigation, where the practice is national in scope ${ }^{56}$ : The opposing attorneys are unlikely to encounter each other in the same district court again, and thus have little incentive to refrain from engaging in unnecessarily combative tactics in order to develop a productive working relationship for future cases. ${ }^{57}$

In addition to attorney self-interest, hyper-contentiousness may also be an artifact of cognitive biases that may prevent attorneys from accurately gauging the relative strengths of their positions in relation to those of their opponents. For example, an attorney may have an inflated view of his abilities, thereby making it difficult for

${ }^{55}$ For example, prosecutors and defense attorneys, who tend to practice in a limited geographic area and/or before a specific court, are known to "get along." See Barry Feld, Criminalizing Juvenile Justice: Rules of Procedure for the Juvenile Court, 69 MINN. L. REV. 141, 187 n.154 (1984) ("Defense attorneys are involved in ongoing relations with prosecutors and judges and become dependent on their cooperation. Similarly, prosecutors and the court depend on defense attorneys to cooperate in order to expedite a large volume of cases."); see also Gary T. Lowenthal, Mandatory Sentencing Laws: Undermining the Effectiveness of Determinate Sentencing Reform, 81 CALIF. L. REV. 61, 78 n.75 (1993) (collecting sources noting cooperative interactions between prosecutors and defense attorneys).

${ }^{56}$ See David L. Schwartz, The Rise of Contingent Fee Representation in Patent Litigation, 64 ALA. L. REV. 335, 347 (2012) ("Patent-litigator practices are frequently national in scope. In other words, patent litigators do not limit their practice to the state in which they reside.").

${ }^{57}$ Cf. John S. Beckerman, Confronting Civil Discovery's Fatal Flaws, 84 MINN. L. REV. 505, 516 n.53 (2000) ("In legal communities in which counsel encounter each other (and judges) repeatedly, anecdotal evidence suggests that 'hardball' and discovery disputes are less common. In large cities where mega-law firms are common and counsel rarely encounter each other (or judges) repeatedly, confrontational behavior and discovery disputes are more common."). 
him to recognize the weaknesses in his arguments. ${ }^{58}$ Likewise, "optimism bias" may cause an attorney to underestimate the likelihood of an adverse ruling. ${ }^{59}$ Notably, the mere circumstance of representing one party against another may be sufficient to skew an attorney's sense of fairness and adversely affect the accuracy of his predictions of how the judge is likely to rule. ${ }^{60}$ In addition, "reactive devaluation," which is the tendency to reflexively discount or reject the opposing party's positions and proposals, may also be a factor in promoting unnecessary bickering between the parties on a range of issues. ${ }^{61}$ Clients may also be affected by these cognitive biases in their decisions to authorize hardball tactics, which may be aggravated by the informational disadvantage under which the clients operate. ${ }^{62}$ In essence, cognitive biases introduce a mismatch between attorney perception

${ }^{58}$ Cf. Justin Kruger \& David Dunning, Unskilled and Unaware of It: How Difficulties in Recognizing One's Own Incompetence Lead to Inflated SelfAssessments, 77 J. PERSONALITY \& SOC. PSYCHOL. 1121, 1127 (1999) ("II]ncompetent individuals fail to gain insight into their own incompetence by observing the behavior of other people. Despite seeing the superior performances of their peers, bottom-quartile participants continued to hold the mistaken impression that they had performed just fine.').

${ }^{59}$ See Christine Jolls, Behavioral Economic Analysis of Redistributive Legal Rules, 51 VAND. L. REV. 1653, 1659 (1998) (citing studies showing that "people are often unrealistically optimistic about the probability that bad things will happen to them").

${ }^{60}$ See Linda Babcock, George Loewenstein, Samuel Issacharoff \& Colin Camerer, Biased Judgments of Fairness in Bargaining, 85 AM. ECON. REv. $1337,1341$ (1995) (reporting experimental results and concluding that "[ $t]$ here was a strong tendency toward self-serving judgments of fairness and predictions of the judge's award when subjects knew their roles").

${ }^{61}$ See generally Lee Ross, Reactive Devaluation in Negotiation and Conflict Resolution, in BARRIERS TO CONFLICT RESOLUTION 28 (Kenneth J. Arrow et al. eds., 1995) (defining "reactive devaluation" as "refer[ring] to the fact that the very offer of a particular proposal or concession-especially if the offer comes from an adversary - may diminish its apparent value or attractiveness in the eyes of the recipient" (emphasis in original)); $c f$. Russell Korobkin \& Chris Guthrie, Psychological Barriers to Litigation Settlement: An Experimental Approach, 93 MICH. L. REV. 107, 160 (1994) ("[Our] reactive devaluation work suggests that when an offeror makes a settlement offer, there is a risk that the offeree will devalue that offer and opt for trial, particularly when she feels some ill will toward the offeror.").

${ }^{62}$ See supra note 52 and accompanying text. 
and reality, such that attorneys may insist on pursuing weak claims or defending futile positions until the mismatch is resolved by a ruling from the court, which, given docket congestion, can take a while.

Given the influence of attorney self-interest and cognitive biases on the choice of strategies adopted by the opposing parties, any proposal for decreasing the level of contentiousness must account for them in order to be effective. As discussed previously, ${ }^{63}$ proposals that call for the court to exercise greater control over litigation through additional rules and sanctions ${ }^{64}$ could exacerbate the problem by creating satellite litigation. Other proposals, such as additional training, ${ }^{65}$ or the adoption of civility codes by courts and bar associations, ${ }^{66}$ may be limited in their effectiveness because they focus primarily on the transmission of knowledge rather than overcoming the influence of attorney self-interest and cognitive biases that shape attorneys' perceptions of the desirability of certain tactics. That is, contentious behavior may be less a function of a lack of knowledge, and more a function of a lack of motivation to act otherwise.

Accordingly, to counter the influence of attorney self-interest and cognitive biases that drive hardball tactics, it may be necessary to change the litigation environment so as to cause the parties to recalibrate what they perceive to be in their self-interest, as well as to counteract the parties' cognitive biases by providing a "reality check" without waiting for the court to issue a ruling. One way to accomplish this is to add a neutral litigant, which will be described in greater detail in the next section.

\section{HI. Litigation Dynamics with a NeUtral Litigant}

To mitigate or counteract the influence of attorney self-interest and cognitive biases described in Part II that promote unnecessary contentiousness, this Article proposes adding an independent, neutral third party litigant charged with representing the public

\footnotetext{
${ }^{63}$ See supra notes $28-37$ and accompanying text.

${ }^{64}$ See, e.g., Cramton, supra note 46, at 1609-14.

${ }^{65}$ See, e.g., Interim Report, supra note 32, at 411-13.

${ }^{66}$ See, e.g., id. at 414-16.
} 
interest to district court patent cases. Drawing on lessons from the International Trade Commission ("ITC") and the Solicitor General's amicus practice before the Supreme Court, Part III presents a neutral litigant model, along with a game theoretic analysis of the litigation dynamics with a neutral litigant.

\section{A. Lessons from the ITC and the Solicitor General}

To illustrate the litigation dynamic that is expected to result with a neutral litigant, the experience of the ITC is particularly instructive.

The ITC is an independent federal agency that administers U.S. trade remedy laws, ${ }^{67}$ and is authorized to investigate, among other things, the importation of goods alleged to infringe U.S. patents under Section 337 of the Tariff Act of 1930, codified as amended at 19 U.S.C. $\S 1337 .^{68}$ In substance, Section 337 actions largely resemble district court patent litigation. ${ }^{69}$ However, a notable difference is that, in addition to the patentee and the accused infringer, a staff attorney from the ITC's Office of Unfair Import Investigations ("OUII") may participate as a neutral, independent litigant with full party status ${ }^{70}$ who represents the public interest. ${ }^{71}$

The presence of the ITC staff attorney as a neutral third party litigant creates a litigation dynamic in Section 337 actions that is

${ }^{67}$ See generally U.S. INT'L TRADE COMM'N, http://www.usitc.gov/ press_room/about_usitc.htm (last visited May 18, 2012).

${ }^{68} 19$ U.S.C. $\$ 1337(\mathrm{a})(1)(\mathrm{B})(2006)$. Section 337 proceedings are governed by the Administrative Procedure Act, 5 U.S.C. $\$ \S 551$ et seq., the Commission Procedural Rules, 19 C.F.R. Part 210, and the Ground Rules of the presiding Administrative Law Judge (ALJ). Section 337 Investigations at the U.S. International Trade Commission: Answers to Frequently Asked Questions, Pub. No. 4105 at 1 (2009) [hereinafter Section 337 FAQ], available at http://www.usitc.gov/intellectual_property/documents/337_faqs.pdf.

${ }^{69}$ Section 337 FAQ, supra note 68 , at 2.

${ }^{70}$ Id. ("The investigative attorney is a full party to the investigation."). The ITC staff attorney is formally known as the "Commission Investigative Attorney." 19 C.F.R. $§ 210.3$ (2012). The staff attorney is often referred to simply as "the Staff."

${ }^{71}$ Marcia H. SundeEn, John W. Bateman, JefFrey S. Gerchick \& T. Cy WALKER, UNFAIR COMPETITION AND THE ITC $\S 2: 4, \S 12: 6$ (West 2010). 
different from district court litigation. ${ }^{72}$ As a full party, the ITC staff attorney may participate in all aspects of the case-discovery, motion practice, trial, and settlement-alongside the private parties $^{73}$ in order to ensure that the contested issues are decided in a fair and reasoned manner, based on a full and complete record, consistent with the public interest. ${ }^{74}$ Regarding discovery practice, the ITC staff attorney may propound discovery, receive discovery responses, question witnesses at depositions, and participate in meet-and-confers. ${ }^{75}$ However, the ITC staff attorney himself is generally not subject to discovery by the other parties, given the staff attorney's special responsibilities and the fact that he is not an original source of information. ${ }^{76}$ When a motion is filed, the ITC staff attorney may file a response during the briefing period to express the views of the OUII on an issue-by-issue basis. ${ }^{77}$ During trials, or "hearings" in ITC parlance, ${ }^{78}$ the ITC staff attorney may

72 MARK LYON \& SARAH PIEPMEIER, ITC SECTION 337 InVESTIGATIONS: PATENT INFRINGEMENT ClAIMS at 4 (2011), available at http://www.gibsondunn.com/publications/Documents/LyonPiepmeier-ITCSec tion337Investigations.pdf ("The typical plaintiff-defendant dynamic is quite different when a neutral third party is also participating in the litigation .... [U]nderestimating the Staff's importance and role is a typical and sometimes costly mistake for new ITC litigants.").

${ }^{73}$ See SUNDEEN ET AL., supra note 71 , at $\$ 12: 6$ ("The [ITC] staff attorneys will participate in all conferences of the parties, the discovery and motions practice, and the hearing, and submit post-hearing briefs.").

${ }^{74} I$ d. at $\S 2: 4, \S 12: 6$.

75 See id. at $\$ 2: 4$; Peter S. Menell, G. Brian Busey, Ruffin Cordell, Mark G. Davis, Matthew D. Powers, \& Sturgis M. Sobin, Section 337 PATENT INVESTigation MANAgEMENT Guide 1-20, 4-22 (2010) [hereinafter SECTION 337 GUIDE], available at $\mathrm{http}: / /$ ssrn.com/abstract $=1603330$.

${ }^{76}$ SUNDEEN ET AL., supra note 71 , at $\$ 4: 50$ (noting that discovery of the staff attorney by another party is inappropriate absent a showing that the information sought is necessary, that its absence would result in prejudice, and that it cannot be obtained from another source without undue hardship).

${ }^{77} Q \& A$ With T. Spence Chubb of WilmerHale, ITC 337 LAw BLOG (Aug. 27, 2010) [hereinafter Spence Chubb Q\&A], http://www.itcblog.com/20100827/q-awith-t-spence-chubb-of-wilmerhale ("[B]ecause OUII takes a position on all of the issues on an issue by issue basis (down to the level of the individual elements of a patent claim), OUII's positions are usually not entirely on the side of one of the private parties or the other, but are instead a 'mixed bag." ").

${ }^{78}$ In Section 337 actions, the trials are evidentiary hearings that resemble bench trials in district court litigation. Section $337 F A Q$, supra note 68, at 2. 
examine witnesses and submit pre- and post-hearing briefs. ${ }^{79}$ The ITC staff attorney may also facilitate settlement ${ }^{80}$ as well as review proposed settlement agreements to ensure they do not contain provisions that are contrary to the public interest. ${ }^{81}$ To be clear, the ITC staff attorney is an actual party to the investigation and is not a judicial adjunct, such as a special master or a magistrate judge. As such, the ITC staff attorney does not engage in any ex parte communications with either the administrative law judge ("ALJ") who presides over the action or the ITC Commissioners who review the ALJ's decisions. ${ }^{82}$

For the ALJ who presides over a Section 337 action, the ITC staff attorney's filings often help illuminate the issues from a disinterested $^{83}$ viewpoint, especially on discovery matters ${ }^{84}$ and

${ }^{79}$ See SUNDEEN ET AL., supra note 71, at $\$ 12: 6$.

${ }^{80} \mathrm{Id}$. (noting that ITC staff attorney may "serv[e] as an ombudsman to facilitate a settlement agreement in appropriate cases").

${ }^{81}$ MENEll ET AL., SECTION 337 GuIDE, supra note 75, at 10-5, 10-6 ("[T] he OUII will be vigilant to make certain that settlements do not adversely affect the public by, for example, imposing unlawful pricing restrictions or other anticompetitive terms.").

${ }^{82} \mathrm{Id}$. at 1-19.

${ }^{83}$ See Charles H. Sanders, Will ITC Staffing Changes Make Future Section 337 Litigation More Like Federal Court?, GoODWIN Proctor 2 (Apr. 5, 2011), available at http://www.goodwinprocter.com/Publications/Newsletter-Articles/ IP-Articles/2011_04/05_01.aspx ("[I]n its role of representing the public interest, the Staff provided parties with a neutral view of the merits before the parties receive the ALJ's [rulings].”). The ITC staff attorneys do not have a propatent or protectionist agenda. Spence Chubb $Q \& A$, supra note 77 ("It should be kept in mind that OUII makes a decision on how to argue the merits based upon how it views the evidence and the law, not based upon any political considerations or any protectionist or pro-patent leanings.").

${ }^{84}$ The ITC staff attorney's views on the parties' discovery motions may be particularly helpful to the ALJ in light of the ITC staff attorney's ability to observe the behavior of the parties' attorneys during discovery, which occurs largely out of the view of the judge. Cf. James L. Duncan, Origin, History and Role of the Office of Unfair Import Investigations, THE 337 REPORTER 25, 26 (2006) ("This staff [attorney] would be the "eyes and ears of the Commission on the street,' with the important responsibility of creating a full record so that the Judges and Commission could make a correct and fully informed decision." (quoting interview with Arthur Wineburg, former OUII Director (July 2006))). 
dispositive motions. ${ }^{85}$ Because the ITC staff attorneys' briefs contain impartial analyses of the disputed issues, they are deemed particularly persuasive by the ALJs: According to one study, the ALJs agreed with the ITC staff attorneys' positions over eighty percent of the time. ${ }^{86}$ Because the ITC staff attorney's views carry considerable weight with the ALJ, ${ }^{87}$ the presence of the ITC staff attorney has been observed to exert a moderating effect on the parties' manner of litigation: Experienced practitioners consider it strategically advantageous to maintain credibility with the ITC staff attorney-often informally vetting their positions on discovery issues ${ }^{88}$ and potential dispositive motions ${ }^{89}$ with himlest the ITC staff attorney oppose their positions or motions before the ALJ. ${ }^{90}$ That is, the parties perceive a strategic need to "pick

${ }^{85}$ Menell Et Al., SeCtion 337 Guide, supra note 75, at 6-7 ("[T]he independent analysis of the OUII staff attorney ... may be of particular value to the ultimate decision makers especially if the OUII staff attorney has undertaken a complex analysis or has pointed to unique policy reasons that warrant a grant or denial of the motion.").

${ }^{86}$ Jerold B. Murphy, A Statistical Comparison of the Staff Attorneys' Positions on Disputed Issues and the Administrative Law Judges' Decisions on Such Issues, 21337 REPORTER 53, 54 (2005) ("The Staff attorney's position and the Judge's holding was compared on a total of 90 disputed issues from the 7 IDs [initial determinations]. The Judges adopted the Staff attorney's position on $81.3 \%$ of the disputed issues.").

${ }^{87}$ See, e.g., SUNDEEN ET AL., supra note 71, $\& 12: 6$ ("As a party without a stake in the outcome, the staff attorney's position may be quite persuasive."); LYON \& PIEPMEIER, supra note 72, at 4 ("Depending on the ALJ, the Staff can have a tremendous influence on procedural issues.").

${ }^{88} \mathrm{Cf}$. Sanders, supra note 83, at 2 ("[T] he Staff typically moderated discovery disputes, frequently leading to informal resolution.").

${ }^{89}$ See MENell ET AL., SECTION 337 Guide, supra note 75, at 6-12 ("Nearly all litigants will reach out to the OUII staff attorney before filing any motion for summary determination.").

${ }^{90}$ Spence Chubb $Q \& A$, supra note 77 ("[W] agree with OUII's positions, they ... always take OUII's positions into serious consideration.... Thus, being able to convince the assigned OUII staff attorney of the reasonableness of the client's positions on the issues is generally perceived as an advantage ...."); LYON \& PIEPMEIER, supra note 72, at 4 ("It is important to develop a good working relationship with the Staff and to attempt to convince them of your positions. . . More importantly, it can be advantageous to have the Staff arguing in favor of your position on the merits. This is because the Staff can often advance policy or public interest arguments that a 
their battles" and refine their positions in light of the ITC staff attorney's views, which may help decrease the quantity while increasing the quality of the motions filed, issues raised, and arguments presented by the parties.

In short, a positive collateral effect of the ITC staff attorney's presence in Section 337 actions has been that it may induce the parties to temper their contentiousness as a matter of strategic necessity, so as to appear credible in order to gain the support of, or, alternatively, to mitigate any potential damage when opposed by, the ITC staff attorney on a given issue. Indeed, when the ITC recently announced that the participation of the ITC staff attorneys would be limited in future cases because of budget constraints, ${ }^{91}$ some practitioners surmised that Section 337 actions could take longer and resemble the more contentious dynamic of district court litigation..$^{22}$

In comparing patent litigation in the district courts versus the ITC, some may question whether the ITC staff attorney's presence actually gives rise to a collateral moderating effect because ITC cases appear to be just as hard-fought (if not more so) than district court cases. ITC cases can be particularly intense because: (1) the infringement claims tend to be more substantive than those filed in the district courts because of the detailed pleading required to

complainant or respondent might not credibly be able to make."); G. Brian Busey, An Introduction to Section 337 and the U.S. International Trade Commission, 949 PLI/Pat 11, 15 (2008) ("[T] he Staff"s views may sometimes be given greater deference by the ITC ALJs. It is therefore important for a party also to persuade the Staff of the merits of its positions during the course of an investigation.").

${ }^{91}$ See Adjudication and Enforcement, 76 Fed. Reg. 24363 (May 2, 2011) (to be codified at 19 C.F.R. pt. 210); Ryan Davis, OUII To Reduce Role In ITC 337 Cases, LAw360 (May 3, 2011), http://www.law360.com/articles/242642/ print? section=ip.

${ }^{92}$ See Sanders, supra note 83, at 2 ("Without the Staff's moderating influence in discovery disputes, litigants might also anticipate increased discovery motion practice. This could extend proceedings and time to disposition. . . . [L]itigants should expect ITC litigation . . . to begin to look more like patent litigation in federal district court."). 
initiate a Section 337 investigation; ${ }^{93}$ (2) the rules governing discovery in ITC cases tend to be less strict than the Federal Rules $;{ }^{94}$ and (3) ITC investigations operate on an expedited timetable compared to district court cases, whereby the ITC endeavors to complete most investigations within fifteen months. ${ }^{95}$ Given the better "vetting" of infringement claims prior to filing suit, fewer procedural constraints, and a faster case timetable, the potential for discovery abuse and aggressive motion practice is magnified in ITC cases, which are far less likely to settle than district court cases. ${ }^{96}$ Accordingly, the level of contentiousness in an ITC case without an ITC staff attorney is likely far higher than that of a district court patent case.

To quantify the collateral moderating effect of the ITC staff attorney, it is necessary to compare ITC cases that have a staff attorney with those that do not, rather than comparing an ITC case with a district court case. As of the time of writing, a meaningful empirical analysis of the ITC staff attorney's moderating effect could not be undertaken because every Section 337 investigation included a staff attorney until mid-2011. ${ }^{97}$ Now, the ITC staff attorney participates in only a subset of the investigations initiated each year. ${ }^{98}$ Because the current rate at which Section 337

93 See LYON \& PIEPMEIER, supra note 72 , at 7 ("A detailed [pre-filing] investigation is necessary because the ITC is a fact pleading venue and requires detailed factual allegations, included [sic] detailed claim charts for all patent claims asserted.").

${ }^{94}$ See MENELL ET AL., SECTION 337 GuIDE, supra note 75, at 4-3 ("The scope of discovery before the ITC is generally broader than that before the District Courts. . . Section 337 investigations typically permit not only more discovery requests but also more and longer depositions.").

${ }^{95}$ See Section 337 FAQ, supra note 68, at 23.

${ }^{96}$ Colleen V. Chien, Patently Protectionist? An Empirical Analysis of Patent Cases at the International Trade Commission, 50 WM. \& MARY L. REV. 63, 100 \& Table 10 (2008) ("ITC litigants were considerably less likely to settle. While nearly 70 percent of district court cases settled, only 42 percent of parties to ITC investigations settled....").

${ }^{97}$ See Davis, supra note 91.

${ }^{98}$ See id. 
investigations are instituted averages less than a hundred per year, ${ }^{99}$ several years would need to pass before a sufficient number of cases without ITC staff attorneys will have terminated so as to allow a dataset to be created that would enable relevant parameters to be meaningfully compared and tested for statistical significance. In the absence of an empirical study, support for the existence of the ITC staff attorney's collateral moderating effect is grounded in the well-documented perceptions and "best practices" of ITC practitioners who perceive a general dampening of contentiousness driven by the need to gain the endorsement of, or blunt any objections from, the ITC staff attorney by picking their battles and informally vetting their positions with him. ${ }^{100}$

Despite the procedural differences between the ITC and the district courts, ${ }^{101}$ the moderating effect on the level of contentiousness that arises incidentally from the presence of the ITC staff attorney in Section 337 actions might also be achieved in district court cases with a neutral litigant that is modeled after the ITC staff attorney. Rather than being endemic to ITC proceedings, the moderating effect appears to be an artifact of a litigation environment where each of the opposing parties perceives an immediate strategic need to obtain the support of, or mitigate opposition from, a third, neutral party whose disinterested views are weighed heavily by the judge.

Indeed, a similar moderating dynamic has also been observed in the context of the Solicitor General's amicus practice before the Supreme Court. When the Solicitor General files an amicus brief during the merits stage and participates in oral argument, he is acting as a neutral litigant in a three-sided litigation environment along with the petitioner and the respondent. Like the patent litigators at the ITC who informally vet their positions with the

99 The U.S. International Trade Commission maintains a webpage with statistics on Section 337 Investigations at http://www.usitc.gov/press_room/ 337 stats.htm (last visited Feb. 17, 2013). That page includes a link to a document listing the number of Section 337 Investigations instituted each calendar year between 1972 through 2012. http://www.usitc.gov/intellectual_ property/documents/cy_337_institutions.pdf (last visited Feb. 17, 2013).

${ }^{100}$ See supra notes $8 \overline{8}-90$ and accompanying text.

${ }^{101}$ See supra notes 93-95 and accompanying text. 
ITC staff attorney, seasoned Supreme Court practitioners will similarly vet their positions with the Solicitor General in the course of preparing their briefs, which may result in the petitioner and the respondent streamlining their arguments in light of potential support or opposition from the Solicitor General. ${ }^{102}$ That the petitioner and the respondent may find it necessary, as a matter of strategy, to present more refined and less extreme positions in light of the Solicitor General's views reflects the degree to which the Supreme Court finds the Solicitor General's views persuasive: ${ }^{103}$ When the Solicitor General participates as amicus, he is on the winning side $70-80 \%$ of the time ${ }^{104}$ and has a statistically significant impact on the outcome for the petitioner and the respondent. ${ }^{105}$ Like the ITC staff attorney, the Solicitor General's reputation for objectivity is a key factor in his success as amicus before the Supreme Court. ${ }^{106}$

102 See Patricia A. Millett, "We're Your Government and We're Here to Help": Obtaining Amicus Support from the Federal Government in Supreme Court Cases, 10 J. APP. PraC. \& Process 209, 227 (2009) (noting that meeting with the Solicitor General will "allow counsel to develop her own briefing strategy based on insights gained from those discussions and, in particular, will allow formulation of her brief in a way that either takes advantage of any support provided by the Solicitor General's position or mitigates the harm inflicted by it").

${ }^{103}$ See Margaret Meriwether Cordray \& Richard Cordray, The Solicitor General's Changing Role in Supreme Court Litigation, 51 B.C. L. REV. 1323, 1337 (2010) ("The Solicitor General's established reputation and enhanced credibility cause justices and their clerks to rely heavily on the Solicitor General's briefs.").

${ }^{104}$ Id. at $1335 \&$ n. 55 (collecting studies).

${ }^{105}$ Joseph D. Kearney \& Thomas W. Merrill, The Influence of Amicus Curiae Briefs on the Supreme Court, 148 U. PA. L. REV. 743, 810 (2000) (conducting empirical analysis and concluding that " $t]$ he Solicitor General's amicus briefs have a statistically significant impact on outcomes (all other variables held constant) for both the petitioner's and respondent's side"). For example, the Solicitor General's support increases the petitioner's chances of winning by approximately $17 \%$ on average, whereas the Solicitor General's support for the respondent decreases the petitioner's chances of winning by approximately $26 \%$ on average. $I d$. at $803-04$.

${ }^{106}$ Id. at 818-19 ("Both the Justices themselves and close observers of the Solicitor General's office attribute the high rate of success to the Solicitor General's reputation for objectivity in accurately stating the law."). 


\section{B. Essential Characteristics and Effects}

Much like the dynamics within a Section 337 action at the ITC or the Solicitor General's amicus practice before the Supreme Court, ${ }^{107}$ the presence of a neutral litigant could similarly improve the litigation dynamics of a district court case so as to decrease the overall level of contentiousness. Notably, "playing traffic cop" need not be a conscious objective of the neutral litigant, whose specific role would be to represent the public interest. Rather, as illustrated in the previous section, ${ }^{108}$ the neutral litigant's moderating influence on the parties' tendency to engage in overly aggressive litigation is a collateral effect arising from the parties recalibrating their strategies so as to better align themselves with, or blunt the impact of any criticisms from, the neutral litigant, whose disinterested analysis the court may find particularly persuasive.

The key characteristics of a suitable neutral litigant at the district court level may be distilled from the relevant characteristics of the ITC staff attorney, ${ }^{109}$ as follows:

(1) Purpose: The neutral litigant's purpose would be to represent the public interest in the fair, accurate, efficient, and just resolution of patent disputes, ${ }^{110}$ and to contribute to the development of case law that strikes the proper balance of interests among the patentee, the accused infringer, and the public at large. ${ }^{11}$ The impartiality of the neutral litigant is critical to producing the collateral moderating influence on the parties' tendency to engage in hyper-aggressive, overly contentious advocacy. ${ }^{112}$ Otherwise, if the neutral litigant is perceived as having a partisan agenda, the court may discount its views, and the parties may not perceive a strategic need to moderate their positions, if the neutral litigant is expected to reliably side with (or against) one of the parties regardless of the merits.

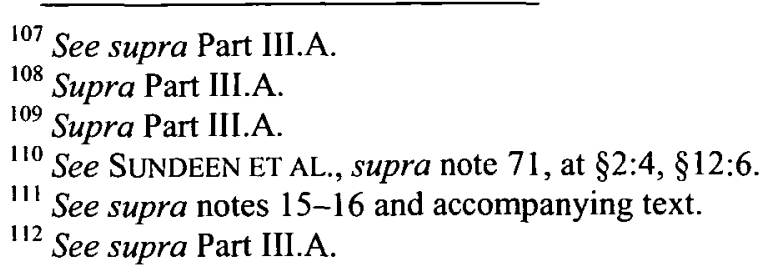


(2) Relationship with Court and Parties: As an actual participant in the litigation, the neutral litigant would not have any ex parte communications with the court, so as to minimize the danger of the neutral litigant improperly influencing, or being influenced by, the court. ${ }^{113}$ The parties, however, may communicate ex parte with the neutral litigant (e.g., to informally vet potential motions). ${ }^{114}$ Absent special reasons, the neutral litigant would be subject to the same procedural rules that apply to the parties.

(3) Scope of Activities: The neutral litigant would be involved in the case on a day-to-day basis, participating in discovery, claim construction, and motion practice in all stages of the litigation (i.e., pre-trial, trial, and post-trial) relating to all issues (e.g., procedural matters, patent liability, and remedies). ${ }^{115}$ During the discovery period, the neutral litigant would propound discovery and participate in depositions, but discovery generally may not be taken of the neutral litigant itself. ${ }^{116}$ For the claim construction process and motion practice, the neutral litigant's participation could take the form of filing responses to the parties' submissions during the briefing period that set forth its views on an issue-byissue basis ${ }^{117}$ based on an impartial analysis of the facts and the law, while highlighting any public interest considerations. The parties should have an opportunity during the briefing period to respond to the neutral litigant. Based on the preferences of the district court, the neutral litigant could also participate in bench trials. The participation of the neutral litigant in jury trials should be evaluated by the court for potential juror confusion as well as possible prejudice arising from the considerable weight the jury might accord the views of a disinterested entity. However, the neutral litigant could observe the proceedings and participate in the briefing of any motions the parties file during and after trial. Finally, the court could allow the neutral litigant to review

\footnotetext{
113 See MEnell ET AL., SECTION 337 Guide, supra note 75, at 1-19.

${ }^{114}$ See id. at 6-12.

${ }^{115}$ See supra text accompanying notes $73-81$.

${ }^{116}$ See SUNDEEN ET AL., supra note 71 , at $\$ 2: 4, \S 4: 50$.

${ }^{117}$ See supra note 77 and accompanying text.
} 
proposed settlement agreements for any adverse impact on the public interest. ${ }^{18}$

As discussed previously, the degree to which the parties may perceive hardball tactics and extreme positions as strategically desirable or feasible may be a function of the attorneys' self-interest as well as any misperceptions of the likelihood of success that may arise from cognitive biases. ${ }^{119}$ The experiences of the ITC staff attorney and the Solicitor General's amicus practice reveal that the presence of a neutral litigant may help redirect and mitigate the adversarial psychology underlying unnecessary contentiousness. ${ }^{120}$ Specifically, the collateral moderating effect arising from the neutral litigant's presence essentially leverages an attorney's self-interest in winning (or saving face): The desire to win (or limit losses) ${ }^{121}$ may induce attorneys to exercise greater care in their choice of motions, issues, positions, and arguments in order to gain the support of, or minimize any disagreements with, the neutral litigant, whose disinterested assessment of the merits may be influential with the court. ${ }^{122}$ Relatedly, the neutral litigant's views on an issue would serve as an early "reality check" during motion practice that may help mitigate the cognitive biases that underlie the pursuit of unreasonable positions and any needless escalation of the dispute while the parties are awaiting a ruling from the court.

Notably, the neutral litigant's collateral moderating effect may arise in any aspect of the case in which it participates. For example, during discovery, the neutral litigant's direct knowledge of the parties' behavior-gained from its day-to-day interaction with the parties-will inform the positions it takes in response to the parties' discovery-related motions (e.g., motion to compel, motion for protective order, motion for sanctions). ${ }^{123}$ As a result, appearing credible to and gaining the support of the neutral litigant on a given discovery issue may become a strategic consideration

\footnotetext{
${ }^{118}$ See MENELL ET AL., SECTION 337 GUIDE, supra note 75, at 10-5, 10-6.

${ }^{119}$ See supra Part II.

${ }^{120}$ See supra Part III.A.

${ }^{121}$ See Schwarzer, supra note 36, at 710; Rhode, supra note 45, at 635 .

122 See supra Part III.A.

${ }^{123}$ See supra note 84 and accompanying text.
} 
for the parties during discovery, in case a party needs to file a discovery motion or oppose one. ${ }^{124}$ Indeed, the participation of the neutral litigant may help defuse the "reactive devaluation" that may occur when parties assess each other's discovery requests: A party may be less inclined to refuse outright a particular discovery request if the neutral litigant also expresses interest in the discovery sought by the other party. ${ }^{125}$ In addition, if the client drives the contentious behavior during discovery (e.g., by refusing to produce any documents), the attorney might have an easier time convincing his client to take a more cooperative approach (e.g., agreeing to a limited production) by citing the need to appear credible to the neutral litigant, especially if the neutral litigant is expected to support the opposing party's motion to compel.

In the context of dispositive motions, the participation of the neutral litigant in the day-to-day litigation among the parties may help decrease both the number of motions and the number of issues that require adjudication, as well as refine the arguments presented in the briefing. ${ }^{126}$ The expected streamlining of motion practice resulting from the neutral litigant's direct participation in the litigation alongside the patentee and the accused infringer is illustrated below in Figure 1.

\footnotetext{
${ }^{124}$ A game theoretic model exploring this dynamic in detail is provided infra Part III.C.

${ }^{125}$ See supra note 61 and accompanying text.

${ }^{126}$ See supra notes 39-40 and accompanying text; Seyfer, supra note 8; supra notes $42-44$ and accompanying text.
} 
Figure 1: Expected Effect of Neutral Litigant on Motion Practice Conventional Motion Practice

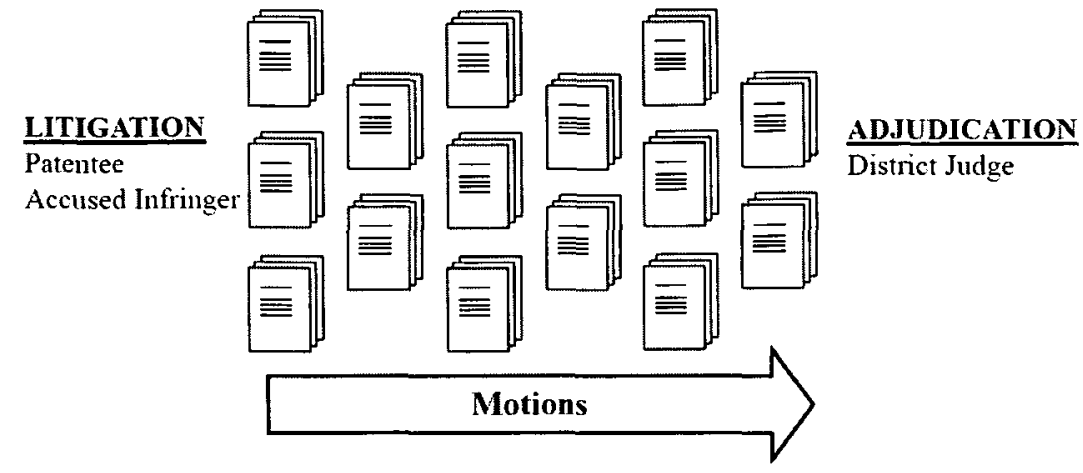

Motion Practice with NeUtral Litigant

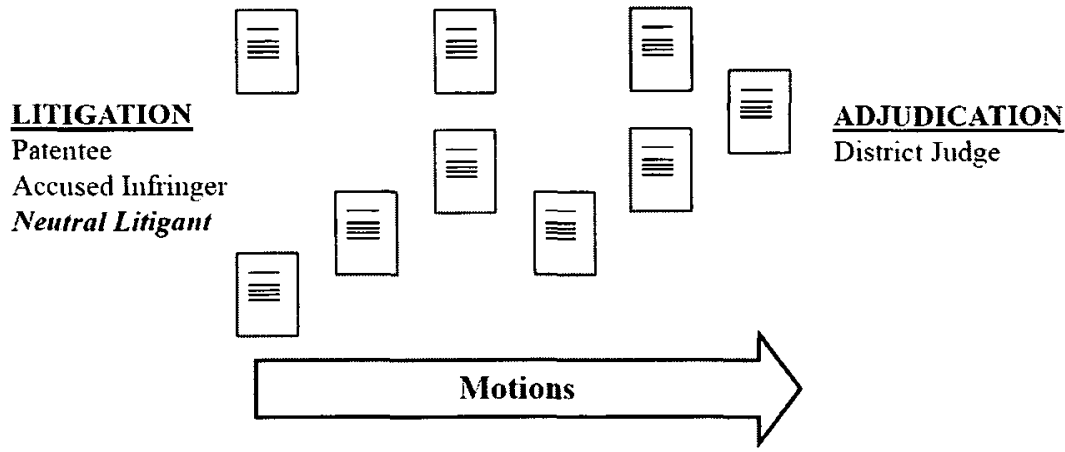

As a participant in the litigation, the neutral litigant would be provided copies of, or access to, all the materials produced during discovery, and can therefore provide the court with a disinterested analysis of the issues that is informed by the full record and goes beyond the parties' tendentious submissions. As such, the neutral litigant's views are likely to be accorded substantial weight by the court, especially if the issue is complex and the parties take extreme, diametrically-opposed positions when the likely "correct" answer lies somewhere in-between. The parties may therefore perceive some strategic value in informally vetting their motions with the neutral litigant prior to filing and/or taking less polarized, more nuanced, positions in order to close any perceived gaps 
between their positions and that of the neutral litigant. And if the neutral litigant joins one of the parties in opposing the other party's motion, the other party will likely provide a more substantive counterargument in its reply (or sur-reply) brief, or even concede a point, rather than respond with a reflexive dismissal of the opposing arguments. In this manner, the neutral litigant's participation may improve the signal-to-noise ratio in motion practice, thereby enhancing the court's ability to adjudicate issues accurately and fairly, and produce rulings sooner and with greater confidence, especially if the judge has limited experience with patent cases or if the issues are extremely complex.

In addition, the neutral litigant's presence may improve the court's ability to rely on procedural rules and the threat of sanctions in managing its docket. The desire to maintain credibility with the neutral litigant may discourage a party from taking unreasonable positions on administrative or procedural issues for purely tactical reasons (e.g., providing insufficient notice for a deposition or opposing a request for an extension of time). If a party files a motion for sanctions, the neutral litigant's viewswhich will be informed by its first-hand knowledge of the parties' interactions - may corroborate, provide greater context to, or refute the allegations in the motion, so that the court will have more detailed, reliable information for deciding whether a violation occurred and crafting an appropriate punishment, if necessary.

Some, however, may question the necessity of a neutral litigant, given that district judges already use a variety of neutral entities to assist with patent cases: magistrate judges, ${ }^{127}$ special masters, ${ }^{128}$ technical advisors, ${ }^{129}$ and court-appointed experts. ${ }^{130}$ Three of these neutral entities-magistrate judges, special masters, and technical advisors - are judicial adjuncts who typically work in

${ }^{127}$ See 28 U.S.C. $\$ 636$ (2006); FED. R. CIV. P. 72.

${ }^{128}$ See FED. R. CIV. P. 53.

129 A district court's ability to appoint a technical advisor falls within its inherent authority. See TechSearch L.L.C. v. Intel Corp., 286 F.3d 1360, 1378 (Fed. Cir. 2002). Technical advisors are essentially "law clerks" with specialized expertise, and do not contribute evidence. See Reilly v. United States, 863 F.2d 149, 157-58 (1st Cir. 1988).

${ }^{130}$ See FED. R. EVID. 706. 
a capacity where they directly assist the district judge with the process of adjudication by presiding over hearings and issuing rulings, ${ }_{131}^{131}$ preparing recommendations for adoption by the court, ${ }^{132}$ and helping the judge understand complex technical subject matter. ${ }^{133}$ In the context of Figure 1 shown above, magistrate judges, special masters, and technical advisors operate at the adjudication stage where motions are decided, rather than at the litigation stage where they are briefed, such that any influence they may have on the parties' strategies and the day-to-day litigation dynamics would be substantially attenuated compared to that of a neutral litigant.

Although the neutral litigant and the judicial adjuncts may have the same primary purpose-that is, to help the court decide issues fairly, accurately, and efficiently - the beneficial effects arising from the neutral litigant's participation in the case occurs "upstream" in relation to the judicial adjuncts. In particular, the collateral moderating effect of the neutral litigant's presence may help decrease the number of motions, narrow the issues, and focus the arguments that are eventually presented to the judge or a judicial adjunct. For example, discovery usually occurs outside the presence of the court-as well as the judicial adjuncts - such that a festering discovery dispute might come to the attention of a judicial adjunct only when a motion is filed. In contrast, a neutral litigant has opportunities to observe and engage with the parties on day-to-day discovery matters, which, as described previously, may create a dynamic that results in fewer discovery motions being filed. ${ }^{134}$ Likewise, in the context of overly-aggressive motion

\footnotetext{
${ }^{131}$ This is a common function of magistrate judges. See 28 U.S.C. $\S 636(b)(1)$ (2006)

${ }^{132}$ See, e.g., Jay P. KeSAN \& GWENDOLYn G. BALl, Fed. Judicial Ctr., A STUdy ÓF THE ROLE AND IMPACT OF SPECIAL MASTERS IN PATENT CASES 7 (2009) (describing function of special masters as including preparing report or recommendation for court and also presiding over hearings).

133 See, e.g., Joshua R. Nightingale, An Empirical Study on the Use of Technical Advisors in Patent Cases, 93 J. PAT. \& TRADEMARK OFF. SOC'Y 400, 414-15 (2011) ("[I]t is nearly universally agreed that a technical advisor's utmost duty lies in educating the judge about the complex technological and scientific principles of a case.").

${ }^{134}$ See supra text accompanying notes 124-125.
} 
practice, a judicial adjunct typically gets involved after the briefing is complete, whereas a neutral litigant would be involved in the briefing process itself, and might also have informally vetted the parties' positions before the motion was filed, such that the issues and arguments ultimately presented in the parties' briefs-for review by the district judge or a judicial adjunct upon completion of the briefing period-are likely to be more streamlined. ${ }^{135}$

The fourth neutral entity, the court-appointed expert under Federal Rule of Evidence 706, does not operate strictly at the adjudication stage because he may be subject to discovery and cross-examination at trial regarding his expert findings relating to a particular subject. ${ }^{136}$ Because the court-appointed expert's disinterested findings may carry considerable weight with the judge or a jury, the court-appointed expert could have a moderating effect on the parties and their experts if they find it strategically necessary to narrow the gap between their positions and the findings of the court-appointed expert when preparing for trial. ${ }^{137}$ However, one or both parties will invariably have concerns about the evidentiary record containing any findings of the courtappointed expert that they perceive as flawed or otherwise irreconcilable with the findings of their own experts. As a result, any moderating effect from the court-appointed expert will be offset by the additional motion practice and satellite litigation by those parties who seek to exclude the court-appointed expert's findings or testimony from consideration by the trier of fact. ${ }^{138}$

\footnotetext{
${ }^{135}$ See supra Part III.A.

${ }^{136}$ FED. R. EVID. 706.
}

137 See James WM. Moore et al., 3-16 MoOre's Federal Practice, Civil $\S 16.36[3][\mathrm{h}][\mathrm{ii}]$ (Matthew Bender, 3d ed.) ("In some cases, appointing a neutral expert could contribute substantially to pretrial efficiencies by ... reducing the adversarial nature of the proceedings, and potentially identifying, clarifying, and narrowing disputed issues.").

${ }^{138}$ See, e.g., Oracle Am., Inc. v. Google Inc., No. 3:10-cv-03561-WHA, ECF No. 891 (N.D. Cal. Apr. 10, 2012) (order on Daubert motions from Oracle and Google seeking to exclude certain portions of report of court-appointed expert); Monolithic Power Sys., Inc. v. O2 Micro Int'l Ltd., No. 4:04-cv-02000-CW, ECF No. 912 (N.D. Cal. Apr. 25, 2007) (objections to testimony of court-appointed expert). 


\section{The Neutral Litigant and Discovery: A Game Theoretic Model}

Because discovery abuse is considered a particularly intractable and pervasive form of unnecessary contentiousness, ${ }^{139}$ it is worth evaluating the potential impact of the neutral litigant in the discovery context in greater detail. Specifically, the litigation dynamics with a neutral litigant may be analyzed with a game theoretic model that illustrates the degree to which the neutral litigant's presence may discourage the parties from taking unreasonable positions and using hardball tactics.

The dynamics of pre-trial civil litigation, and discovery in particular, are often analogized in the scholarly literature to the "Prisoner's Dilemma:" 40 Given the option to behave either cooperatively (i.e., being reasonable) or noncooperatively (i.e., being contentious) during discovery, both parties will engage in noncooperative behavior in an attempt to gain a tactical advantage and to avoid getting taken advantage of by the other side, even though mutual cooperation would provide a more efficient outcome for both parties. ${ }^{141}$ For purposes of analyzing the

${ }^{139}$ In a survey conducted by the Seventh Circuit in the early 1990s, " $94 \%$ [of the practitioners who observed civility problems] target discovery as the primary setting for uncivil conduct." Interim Report, supra note 32, at 380.

${ }^{140}$ See, e.g., John K. Setear, The Barrister and the Bomb: The Dynamics of Cooperation, Nuclear Deterrence, and Discovery Abuse, 69 B.U. L. REV. 569, 586 (1989) ("The Federal Rules of Civil Procedure contain a number of measures that are consistent with an acknowledgement that the practice of discovery presents litigants with a Prisoner's Dilemma."); see also Robert W. Gordon, The Ethical Worlds of Large-Firm Litigators: Preliminary Observations, 67 FORDHAM L. REV. 709, 718 (1998) ("[L]itigation practice is a classic prisoner's dilemma: in many cases both sides would gain more from cooperation, but each stands to lose if he or she cooperates and the other side doesn't.").

${ }^{141}$ See, e.g., Russell G. Pearce \& Eli Wald, The Obligation of Lawyers to Heal Civic Culture: Confronting the Ordeal of Incivility in the Practice of Law, 34 U. ARK. LiTTLE ROCK L. REV. 1, 49 (2011) ("[T]he non-cooperative, autonomous move generally provides the safest chance of winning [in a Prisoner's Dilemma]. This perspective would not only justify the uncivil conduct, but it would also dictate that the proper response to incivility is further incivility. A civil response to an uncivil move would both look weak and be weak."); Ronald J. Gilson \& Robert H. Mnookin, Disputing Through Agents: Cooperation and Conflict Between Lawyers in Litigation, 94 COLUM. L. REV. 509,514 (1994) ("In many disputes, each litigant may feel compelled to make a 
Prisoner's Dilemma model of discovery, "noncooperative" behavior may include: insisting on pursuing overly broad discovery; unreasonably delaying or refusing production of responsive discovery and deposition witnesses; creating administrative or scheduling disputes for tactical reasons; making speaking objections, coaching witnesses, improperly instructing witnesses not to answer, and bullying opposing counsel during depositions; failing to "meet and confer"142 in good faith; and needlessly escalating disputes by filing multiple discovery motions.

The payoffs for each party in the Prisoner's Dilemma model of discovery, as a function of executing either a cooperative strategy or a noncooperative one, may be illustrated as follows:

Figure 2a: Discovery

Strategy Payoff Matrix (Exemplary Values)
Figure 2b: Discovery Strategy Payoff Matrix (Abstract Values)
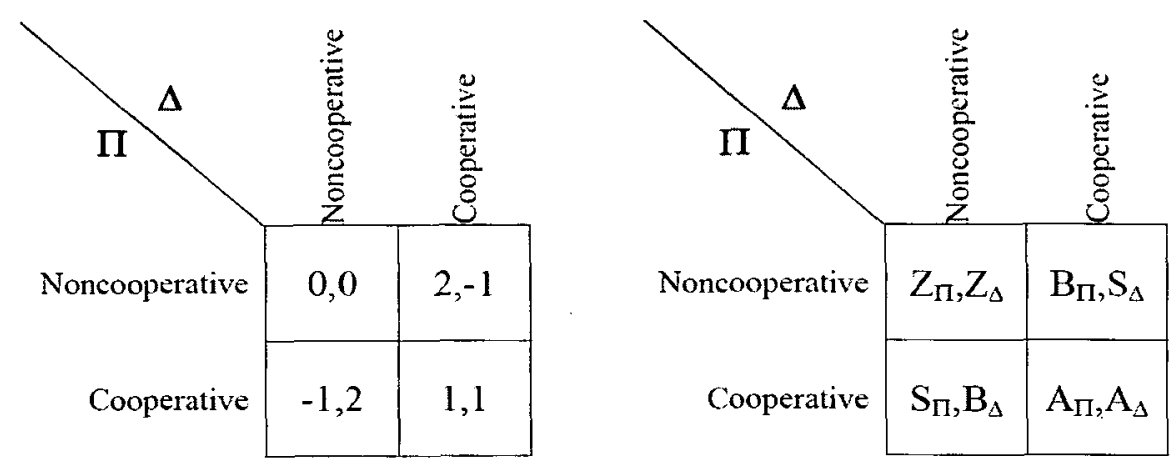

Where: $\mathrm{B}>\mathrm{A}>\mathrm{Z}>\mathrm{S}$

contentious move either to exploit, or to avoid exploitation by, the other side. Yet, the combination of contentious moves by both results in a less efficient outcome than if the litigants had been able to cooperate.").

${ }^{142}$ The local rules of some district courts require parties to meet in person or by telephone and confer about the substance of a motion prior to filing it. See, e.g., E.D. Tex. Local R. CV-7(h) (Feb. 28, 2012), available at http://www.txed. uscourts.gov/cgi-bin/view_document.cgi?document $=1164 \&$ download $=$ true. 
Figure 2a lists exemplary payoffs, whereas Figure $2 b$ provides an abstract representation of the relative numerical relationships that satisfy the conditions of a Prisoner's Dilemma. Each cell in the matrix of Figure $2 a$ shows a pair of numbers representing the respective payoffs of each party for a given strategy against the other party's strategy. The left number in each pair represents the plaintiff's (II) payoff, whereas the right number represents the defendant's $(\Delta)$ payoff. The payoffs in Figure $2 \mathrm{a}$ are as follows:

(i) If both parties cooperate, then both parties benefit such that the payoff for each party is 1 .

(ii) If one party cooperates while the other does not, then the noncooperating party receives a benefit at the expense of the cooperating party, such that the respective payoffs for the noncooperative and cooperative parties are 2 and -1 , respectively.

(iii) If both parties refuse to cooperate, then neither party benefits such that the payoff for each party is 0 .

Given the payoffs in Figure 2a, the strategy of being noncooperative during discovery is the best response for each party to the other party's strategy, regardless of which strategy the other party employs. This conclusion is visually represented in Figure 2c. Specifically, when the defendant acts noncooperatively, the plaintiff's best response is to act noncooperatively as well because the plaintiff's payoff for being noncooperative $(0)$ is higher than its payoff for being cooperative (-1). For visual clarity, the payoff for the plaintiff's best response is denoted by a single underline. Similarly, when the defendant is cooperative, the plaintiff's best response, again, is to be noncooperative because the payoff for noncooperation (2) is higher than that of cooperation (1). Likewise, an analysis of the defendant's best responses to the plaintiff's strategies reveals that being noncooperative yields a higher payoff for the defendant regardless of which strategy the plaintiff chooses. For visual clarity, the payoffs for the defendant's best responses are denoted with double underlining. 
Figure 2c: Figure 2a Annotated with Best Response Payoffs (Single Underline: Plaintiff; Double Underline: Defendant)

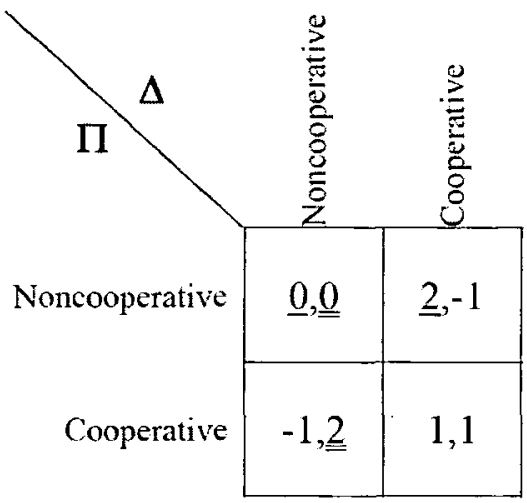

As shown in Figure 2c, mutual noncooperation is the only strategy pair in which each party is playing its best response against the other party, in which neither party has an incentive to unilaterally deviate from its chosen strategy. In game theory parlance, mutual noncooperation is the "Nash equilibrium" $" 143$ in the Prisoner's Dilemma model of the discovery payoff matrix. (Notation-wise, the Nash equilibria in the payoff matrices in this Article will be identifiable whenever both payoff values in a strategy pair contain underlining as a result of having been identified as best responses, such as $\underline{0}, \underline{\underline{0}}$ in Figure 2c.) Although it is possible that some parties might start out cooperating at the beginning of the litigation, their interactions will likely degenerate to an equilibrium of mutual noncooperation as soon as one of the parties acts, or is perceived to act, contentiously. ${ }^{144}$ Likewise, the

${ }^{143}$ Douglas G. Baird, Robert H. Gertner, \& Randal C. Picker, Game THEORY AND THE LAW 22 (1994) ("In a two-person game, a pair of strategies will form a Nash equilibrium when each player cannot do better given the strategy the other player has adopted. A Nash equilibrium, in other words, is a pair of strategies such that each is a best response to the other.").

${ }^{144}$ This is the "grim trigger" strategy for iterated Prisoner's Dilemma games. See Roger A. McCain, Game Theory and Public Policy 99 (2009) (defining "grim trigger" as "[a] rule that plays cooperatively until the other player initiates non-cooperative play and then retaliates by playing non-cooperatively on all successive plays"). 
meta-strategy of "tit for tat" for the iterated Prisoner's Dilemma, which involves a pattern of punishment and forgiveness that may allow the parties to return to mutual cooperation, ${ }^{145}$ is unlikely to be sustained in the typical patent case where the stakes are high and the opposing attorneys and parties are unlikely to encounter each other in future litigation, such that they have little incentive to "forgive" - and risk getting taken advantage of - for a chance at mutual cooperation. ${ }^{146}$

That mutual noncooperation is the Nash equilibrium in the Prisoner's Dilemma version of discovery is attributable to two relationships in the payoff matrix, as expressed in terms of the variables in Figure $2 b$ :

- B > A: The "bastard's payoff," B, which is the payoff for being noncooperative when the other side is cooperating, is higher than the payoff for mutual cooperation, $\mathrm{A}$; and

- S < Z: The "saint's payoff," $\mathrm{S}$, which is the payoff for cooperating when the other side is uncooperative, is lower than the payoff for mutual noncooperation, $\mathrm{Z}$.

Assuming that the payoff for mutual cooperation, $\mathrm{A}$, is greater than the payoff for mutual noncooperation, $Z,{ }^{147}$ the relationships listed above define the critical conditions necessary for noncooperation to be the strictly dominant strategy in the discovery payoff matrix.

In order to change the relative payoffs in the discovery strategy matrix so that one or both of the critical conditions (i.e., $B>A$ and $\mathrm{S}<\mathrm{Z}$ ) that establish mutual noncooperation as the Nash equilibrium are no longer satisfied, one option may be to change the environment in which the parties litigate so as to affect the desirability of a particular strategy. For example, consider the

145 Robert AXELrod, THE EVOlution OF COOPERATION 54 (1984) (characterizing "tit for tat" as "[a] combination of being nice, retaliatory, forgiving, and clear" where "forgiveness helps restore mutual cooperation").

${ }^{146}$ See, e.g., Beckerman, supra note 57, at 516 ("[T] tat' or reciprocity is more likely to be successful when the players encounter each other repeatedly, but less likely to be successful when they do not."); see supra notes 55-57 and accompanying text.

${ }^{147}$ This assumption applies to all the payoff matrices analyzed in this Article. 
difference in the behavior of the parties when examining a witness in the following scenarios: (a) at a deposition during discovery; and (b) in front of a jury during trial. In both scenarios, there is a witness who is being asked questions under oath by one party while another party makes objections from time to time, and a court reporter transcribes the proceeding. Despite these operational similarities, however, depositions commonly involve contentious behavior (e.g., objecting improperly and unnecessarily), ${ }^{148}$ whereas during trial, seasoned practitioners avoid contentiousness while in the courtroom (e.g., objecting sparingly) in order to appear credible and likeable to the jury. ${ }^{149}$ This disparity in the desirability of contentiousness as a strategy appears to be a function of the litigation environment in which the action occurs: Unlike trials, depositions-like most of discovery - occur without the presence of a third party monitor whose views may affect the outcome of the case. ${ }^{150}$ In other words, during discovery, there is

148 See Interim Report, supra note 32, at 388 ("Depositions, conducted by lawyers without direct judicial supervision, can be one of the most uncivil phases of trial practice."); Eric B. Miller, Note, Lawyers Gone Wild: Are Depositions Still a "Civil" Procedure?, 42 CONN. L. REV. 1527 (2010) ("Vulgar and abusive language, witness coaching, 'speaking' objections and improper instructions not to answer, and even physical violence have been known to occur [during depositions] .... These problems arise from the reality that depositions are rarely supervised and largely unregulated.").

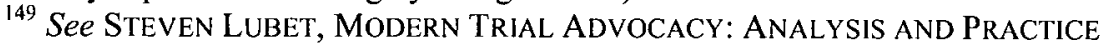
265 (3d ed. 2004) ("In a well-prepared trial involving experienced counsel it would not be surprising for hours, even days, to go by without a single objection. When objections are made they are directed at important items of evidence whose admissibility is seriously in doubt."); Stanley L. Brodsky \& David E. Cannon, Ingratiation in the Courtroom and in the Voir Dire Process: When More is Not Better, 30 LAW \& PSYCHOL. REV. 103, 107 (2006) ("[A]ttorneys engage in both subtle and obvious efforts to make their clients and themselves more likable to the jurors."); Victor Gold, Covert Advocacy: Reflections on the Use of Psychological Persuasion Techniques in the Courtroom, 65 N.C. L. REV. 481, 488 (1987) ("The goal of courtroom style techniques aimed at enhancing attorney credibility is to influence how jurors perceive the evidence. Attorneys can have this influence because jurors tend to evaluate evidence in light of the credibility of the attorneys presenting or attacking that evidence.").

${ }^{150}$ See Interim Report, supra note 32; see also DF Activities Corp. v. Brown, 851 F.2d 920, 923 (7th Cir. 1988) (Posner, J.) ("[B]eing deposed is scarcely less 
no third party audience whose real-time impressions of the parties' actions are of sufficient concern to the parties so as to prompt them to moderate their behavior.

Accordingly, it is expected that, as the third party monitor's influence over case outcomes increases, the strategic value of noncooperation decreases in light of the credibility gains available with a cooperative strategy. The most extreme case of a third party monitor's influence on case outcomes is a jury trial, where the third party monitor is the jury and the judge, who, together, play a direct role in determining the outcome of the trial. Indeed, consistent with the preferred practice of seasoned trial practitioners, ${ }^{151}$ mutual cooperation is the Nash equilibrium when the parties litigate in front of a jury, as shown in the payoff matrix below:

Figure 3a: Jury Trial Strategy Payoff Matrix (Exemplary Values)

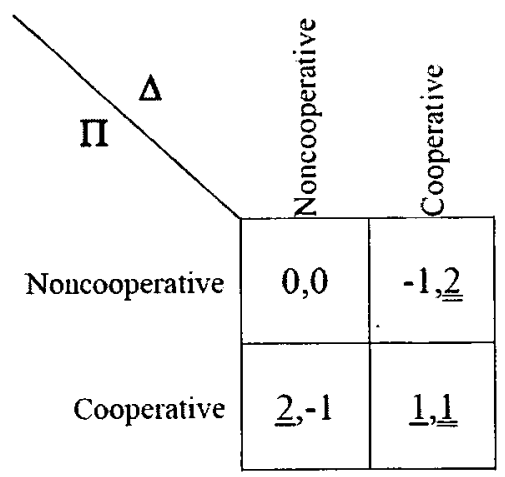

Figure 3b: Jury Trial Strategy Payoff Matrix (Abstract Values)

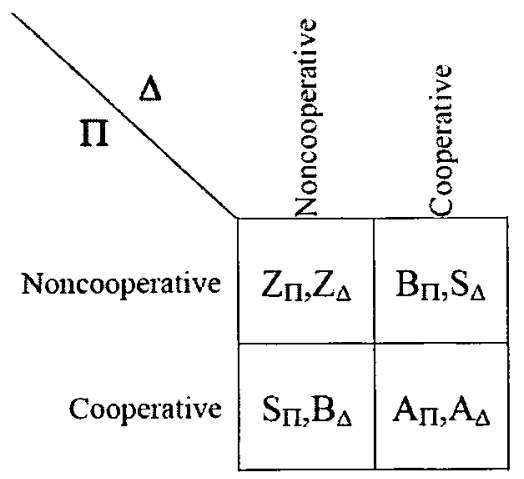

Where: $\mathrm{S}>\mathrm{A}>\mathrm{Z}>\mathrm{B}$

unpleasant than being cross-examined-indeed, often it is more unpleasant, because the examining lawyer is not inhibited by the presence of a judge or jury who might resent hectoring tactics. The transcripts of depositions are often very ugly documents.").

${ }_{151}$ See LUBET, supra note 149 and accompanying text. 
During a jury trial, noncooperative behavior includes objecting frequently and being rude to witnesses and opposing counsel, whereas cooperative behavior includes objecting sparingly and being civil to witnesses and opposing counsel. As shown in Figures 3a and 3b, the "saint's payoff," $S$, is the highest value in the jury trial strategy payoff matrix because the contrast in the behavior of the cooperative "saint" and the noncooperative "bastard" in front of the jury confers a substantial strategic advantage on the "saint" by making him appear more confident, credible, and likable by comparison. Conversely, the "bastard's payoff," B, is the lowest value in the jury trial strategy payoff matrix because the negative contrast with the "saint" poses a substantial handicap to winning over the jury. As a result, as indicated in Figure $3 \mathrm{a}$ by underlining, adopting a cooperative strategy is the best response for each party regardless of the actions of the other party, thereby rendering mutual cooperation the Nash equilibrium in the courtroom during a jury trial.

From the jury trial strategy payoff matrix, we see that the conditions necessary to sustain mutual cooperation as the Nash equilibrium are:

- B $<$ A: The "bastard's payoff," B, is less than the payoff for mutual cooperation, $\mathrm{A}$; and

- $\mathrm{S}>\mathrm{Z}$ : The "saint's payoff," $\mathrm{S}$, is greater than the payoff for mutual noncooperation, $\mathrm{Z}$.

Notably, the above two relationships constitute the reverse of the two corresponding relationships associated with the Prisoner's Dilemma version of the discovery payoff matrix, in which mutual noncooperation is the Nash equilibrium, as summarized below: 
Table 1: Comparison of Nash Equilibria: Discovery vs. Jury Trial

Discovery Strategy Payoff Matrix

Nash Eq.: Noncooperation

Conditions:

B > A : "bastard's payoff"

higher than payoff for

mutual cooperation

$\mathrm{S}<\mathrm{Z}$ : "saint's payoff"

lower than payoff for

mutual noncooperation
Jury Trial Strategy Payoff Matrix

Nash Eq.: Cooperation

Conditions:

B $<$ A : "bastard's payoff"

lower than payoff for

mutual cooperation

$\mathrm{S}>\mathrm{Z}$ : "saint's payoff"

higher than payoff for

mutual noncooperation

The comparison of the Nash equilibria in Table 1 suggests that, at one extreme, mutual noncooperation is the equilibrium state where litigation occurs in the absence of a third party monitor (as in discovery). At the other extreme, cooperation is the equilibrium state when litigation occurs in the presence of a third party monitor who controls the outcome of the litigation (as in a jury trial). Accordingly, the presence of a third party monitor in the form of a neutral litigant, whose views do not control the outcome of the litigation but carry some weight with the court, is likely to have an effect on the discovery payoff matrix that falls somewhere between these two extremes.

In general, the neutral litigant's presence during discovery is expected to increase the payoff for cooperative behavior and decrease the payoff for noncooperative behavior as a result of a party's gain or loss, respectively, of credibility with the neutral litigant. These changes to the payoffs are expected, in turn, to modify the two relationships responsible for establishing noncooperation as the Nash equilibrium (i.e., B $>\mathrm{A}$ and $\mathrm{S}<\mathrm{Z}$ ), so that noncooperation may no longer be the strictly dominant strategy.

With respect to the relationship between the "bastard's payoff" and mutual cooperation (i.e., B > A), the presence of the neutral litigant is unlikely to reverse this relationship. This is because the combined effect of a decrease in B from a loss of credibility and an incremental increase in A from a gain in credibility is not expected 
to be large enough to eliminate the perceived strategic edge attained by unilateral noncooperation. That is, in the presence of a neutral litigant-who, unlike the judge or the jury, does not directly control case outcomes-a party may still perceive the consequences of unilateral noncooperation as tactically more desirable than the consequences of mutual cooperation. However, the loss of credibility associated with unilateral noncooperation will decrease the margin by which B is greater than $\mathrm{A}$.

In contrast, the neutral litigant's presence is expected to reverse the relationship between the "saint's payoff," $S$, and the payoff for mutual noncooperation, $Z$, so that $S>Z$. Specifically, $S$ is expected to substantially increase because of the credibility gains from unilateral cooperation and the potential support available from the neutral litigant in the event a discovery motion may need to be filed against the noncooperating party. At the same time, $\mathrm{Z}$, which is the payoff for the unproductive stalemate resulting from mutual noncooperation, is expected to be lower than $\mathrm{S}$ because the loss of credibility from engaging in mutual noncooperation-and the potential lack of support from the neutral litigant-may make it more difficult to successfully compel discovery or seek a protective order. In short, the presence of the neutral litigant is expected to make unilateral cooperation less risky and more beneficial for a party than engaging in mutual noncooperation.

In essence, the critical relationship that distinguishes a discovery strategy payoff matrix with a neutral litigant from the Prisoner's Dilemma model is that the "saint's payoff" for unilateral cooperation is higher than the payoff for mutual noncooperation (i.e., $\mathrm{S}>\mathrm{Z}$ ). This does not mean, however, that there will never be mutual noncooperation. Because the "bastard's payoff" will still be higher than the payoff for mutual cooperation (i.e., B $>$ A), there will be instances where both parties will end up in a state of mutual noncooperation while both are attempting to gain the "bastard's payoff." Accordingly, the equilibrium state will include a mixture of strategy pairings, as will be explained in reference to Figures $4 a, 4 b, 5 a$ and $5 b$. 
Figure 4a: Discovery

Strategy Payoff Matrix

with Neutral Litigant

(Exemplary Values)

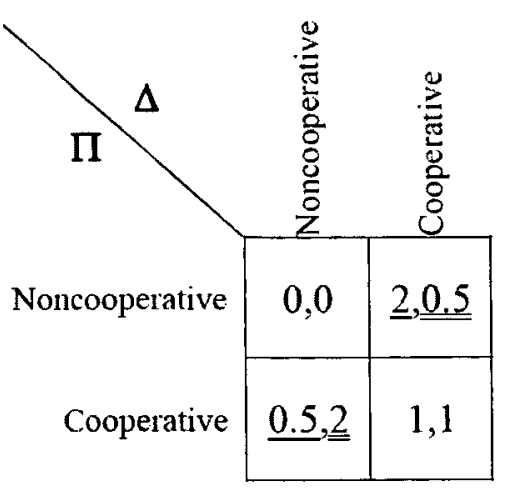

Figure 4b: Discovery Strategy Payoff Matrix with Neutral Litigant (Abstract Values)

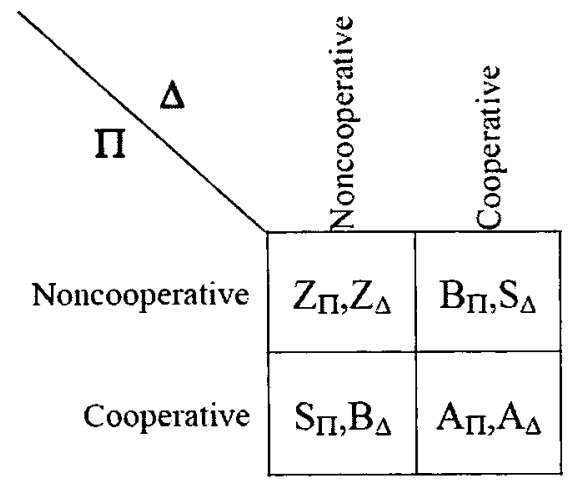

Where: $\mathrm{B}>\mathrm{A}>\mathrm{S}>\mathrm{Z}$

The discovery payoff matrix of Figures $4 a$ and $4 b$, in which the payoffs reflect the presence of the neutral litigant, is a type of game called "Hawk-Dove" or "Chicken," in which there are three Nash equilibria: two "pure-strategy" equilibria and one "mixedstrategy" equilibrium. ${ }^{152}$ To determine which equilibria among the three is the most plausible (i.e., likely to occur in practice), ${ }^{153}$ each will be analyzed in turn.

The two pure-strategy equilibria are denoted by underlining in Figure $4 \mathrm{a}$, which are complementary strategy pairs in which one party cooperates while the other does not. The existence of multiple pure-strategy equilibria presents a coordination problem, which could be solved if the parties were to agree on one of the equilibrium states or were otherwise aware of the other party's chosen strategy before acting. ${ }^{154}$ However, there is no single pure-

152 See Shaun Hargreaves Heap \& Yanis Varoufakis, Game TheOry: A CRITICAL INTRODUCTION 198 (1995); BAIRD ET AL., supra note 143, at 44.

${ }^{153} \mathrm{Cf}$. BAIRD ET AL., supra note 143, at 39 ("If there are ways to identify the one Nash equilibrium that individuals are likely to play and others that they are not, we may still be able to take advantage of the Nash equilibrium concept even when a game has multiple Nash equilibria.").

${ }^{154}$ See id. at $40-41$. 
strategy equilibrium in Figure 4a that will be preferred by both parties or otherwise emerge as a likely focal point because the payoffs for the two equilibria are asymmetric, i.e., $(2,0.5)$ and $(0.5,2)$, with identical combined totals, i.e., 2.5. ${ }^{155}$ More importantly, because the parties are adversarial, each will endeavor to keep the other party guessing about its next move and will likely resist any coordination of strategies. ${ }^{156}$ Accordingly, the two pure-strategy equilibria may not serve as useful models for our analysis because it may not be possible to predict which of the two pure-strategy equilibrium states will occur, ${ }^{157}$ and solving the coordination problem may require a level of information exchange between the parties that is unrealistic in practice.

Fortunately, there is a third Nash equilibrium that may provide a more realistic model of the parties' behavior. In this third equilibrium, each party mixes its strategies by cooperating some portion of the time while not cooperating at other times. Because the parties are adversarial, we can assume that the mixing is not coordinated between the parties, and appears random from the point of view of the other party. ${ }^{158}$ Accordingly, the respective portion of the time when a party adopts a particular strategy (i.e., cooperation or noncooperation) may be expressed as a probabilistic weight, which is a function of the payoffs. ${ }^{159}$ As a result, in this "mixed-strategy" equilibrium, each of the four strategy pairs in the discovery payoff matrix is expected to occur during a case for a specific portion of the time.

For use in calculating the probabilistic weights of the parties' strategies in a "mixed-strategy" Nash equilibrium, Figure 5a reproduces Figure $4 \mathrm{~b}$ with variables representing the probability

155 See id. at 44.

${ }^{156} \mathrm{Cf}$. id. at $40-41$.

157 See HARGREAVES HEAP ET AL., supra note 152, at 70-72; BAIRD ET AL., supra note 143 , at 44.

${ }^{158}$ Cf. HaRGREAVES HEAP ET AL., supra note 152, at 70-72. By way of illustration, mixing one's strategies in a way that appears random and unpredictable to the opponent is common in certain sports and games, e.g., tennis shots, baseball pitches, penalty kicks in soccer, bluffing in poker, etc. See id. at 71 (Box 2.4).

${ }^{159}$ See id. at $72-73$. 
weights for each of the parties' choice of strategies: $p$ and 1-p correspond to the probability weights denoting the portion of the time during a case when the plaintiff will be noncooperative or cooperative, respectively, whereas $d$ and $1-d$ correspond to the probability weights denoting the portion of the time during a case when the defendant will be noncooperative or cooperative, respectively. Because the parties are mixing their strategies according to the probabilistic weights, all four strategy pairs will exist in the proportions specified in Figure $5 \mathrm{~b}$.

Figure 5a: Figure 4b with Probability Weights

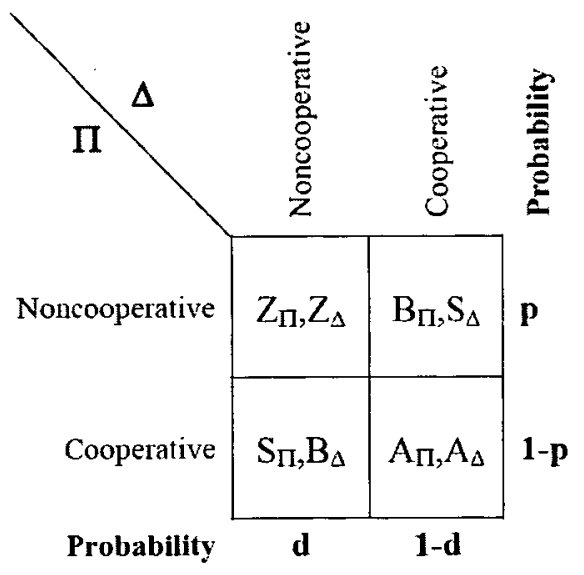

Figure 5b: Distribution of Strategy Pairs in MixedStrategy Equilibrium

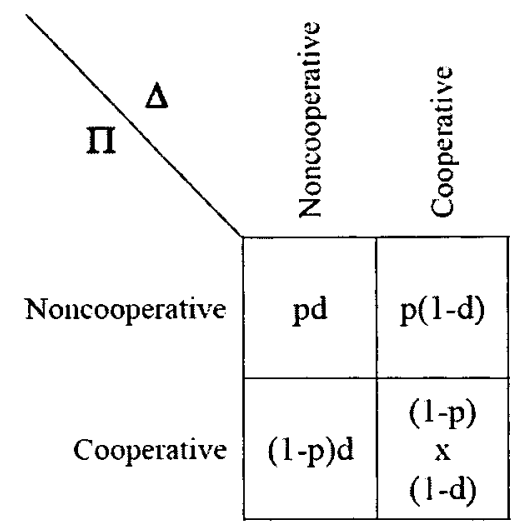

Where: $\mathrm{B}>\mathrm{A}>\mathrm{S}>\mathrm{Z} ; 0<\mathrm{p}<1 ; 0<\mathrm{d}<1$

In a "mixed-strategy" equilibrium, the expected payoff of each component strategy within a party's mix of strategies must be the same. ${ }^{160}$ Specifically, given that the plaintiff is mixing its strategies with probabilities $p$ and 1-p, the defendant's expected payoff in equilibrium from adopting a noncooperative strategy must be equal to its expected payoff from adopting a cooperative

${ }^{160}$ See id. 
strategy against the plaintiff, which may be expressed algebraically as:

$$
\begin{aligned}
Z_{\Delta} p+B_{\Delta}(1-p) & =S_{\Delta} p+A_{\Delta}(1-p) \\
\text { ( }{ }^{\prime} \text { 's Expected Payoff } & (\Delta \text { 's Expected Payoff } \\
\text { from Noncooperation) } & \text { from Cooperation) }
\end{aligned}
$$

Similarly, given that the defendant is mixing its strategies with probabilities $d$ and 1-d, the plaintiff's expected payoff in equilibrium from adopting a noncooperative strategy must be equal to its expected payoff from adopting a cooperative strategy:

$$
\begin{aligned}
& Z_{\Pi} d+B_{\Pi}(1-d)=S_{\Pi} d+A_{\Pi}(1-d) \\
& \text { (II's Expected Payoff (П's Expected Payoff } \\
& \text { from Noncooperation) from Cooperation) }
\end{aligned}
$$

After simple algebraic operations, the following expressions may be obtained for $\mathrm{p}$ and $\mathrm{d}$, which are the respective portions of the plaintiff's and defendant's strategy mixes where they behave noncooperatively:

$$
\begin{gathered}
\mathrm{p}=\left(\mathrm{B}_{\Delta}-\mathrm{A}_{\Delta}\right) /\left(\mathrm{S}_{\Delta}-\mathrm{Z}_{\Delta}+\mathrm{B}_{\Delta}-\mathrm{A}_{\Delta}\right) \\
\mathrm{d}=\left(\mathrm{B}_{\Pi}-A_{\Pi}\right) /\left(\mathrm{S}_{\Pi}-\mathrm{Z}_{\Pi}+\mathrm{B}_{\Pi}-A_{\Pi}\right)
\end{gathered}
$$

To streamline the above expressions for $\mathrm{p}$ and $\mathrm{d}$, we can substitute $\Delta_{\mathrm{BA}}$ for B-A and $\Delta_{\mathrm{SZ}}$ for S-Z to arrive at the following expressions (the additional bracketed subscripts, [ $\Pi]$ and $[\Delta]$, denote which parties' payoffs (plaintiff's or defendant's) are being used in the calculation):

$$
\begin{aligned}
& \mathrm{p}=\Delta_{\mathrm{BA}[\Delta]} /\left(\Delta_{\mathrm{SZ}[\Delta]}+\Delta_{\mathrm{BA}[\Delta]}\right) \\
& \mathrm{d}=\Delta_{\mathrm{BA}[\Pi]} /\left(\Delta_{\mathrm{SZ}[\Pi]}+\Delta_{\mathrm{BA}[\Pi]}\right)
\end{aligned}
$$

Notably, the streamlined expressions for $\mathrm{p}$ and $\mathrm{d}$ make it clear that the probability weights denoting the proportion of the time that a party will be noncooperative in a "mixed-strategy" equilibrium is a function of the other party's payoffs. In the context of litigation, one possible interpretation of this result is that a party will 
calibrate the need to be contentious based on the observed tendencies of the other party. Take Eq. 1, for example: If the defendant tends to overvalue its "bastard's payoff" for unilateral noncooperation such that $\Delta_{\mathrm{BA}[\Delta]}$ is large or undervalues the "saint's payoff" for unilateral cooperation such that $\Delta_{\mathrm{SZ}[\Delta]}$ is small, then the defendant will behave in a manner such that the proportion of the time, $\mathrm{p}$, that the plaintiff will perceive the need to employ a noncooperative strategy against the defendant will be high. Conversely, if the defendant's preferences were the opposite, i.e., $\Delta_{\mathrm{BA}[\Delta]}$ is small and/or $\Delta_{\mathrm{SZ}[\Delta]}$ is large, then the proportion of the time that the plaintiff would find it necessary to act noncooperatively would be lower.

The values for $\Delta_{\mathrm{BA}}$ and $\Delta_{\mathrm{SZ}}$ would be established early in the case when the parties, along with the neutral litigant, are getting acquainted with each other's litigation styles. ${ }^{161}$ The values for $\Delta_{\mathrm{BA}}$ and $\Delta_{\mathrm{SZ}}$, and consequently, $\mathrm{p}$ and $\mathrm{d}$, which govern the probabilistic mix of strategies used by the parties, are expected to remain stable throughout the case in the absence of a substantial change in the litigation environment, such as a change in counsel by one of the parties or the removal of the neutral litigant. The values of $\Delta_{\mathrm{BA}}$ and $\Delta_{\mathrm{SZ}}$ in a given case may depend on, among other things: the personalities, group dynamics, and firm culture of the attorneys (and their clients); the degree to which the neutral litigant is active in the litigation and is able to redirect and mitigate the effects of attorney self-interest and cognitive biases; and the amount of weight that the judge tends to give the neutral litigant's views.

To see how a "mixed-strategy" equilibrium works with actual values, Figure 6a specifies the probability weights for each party's strategy for the matrix of Figure $4 \mathrm{a}$, and Figure $6 \mathrm{~b}$ provides the probability of occurrence for each of the four strategy-pairs:

${ }^{161}$ As mentioned previously, patent litigation tends to be a national practice, such that the opposing attorneys are unlikely to have encountered each other in prior litigation before the same judge. See Schwartz, supra note 56, at 347 . 
Figure 6a: Figure 4a with

Probability Weights

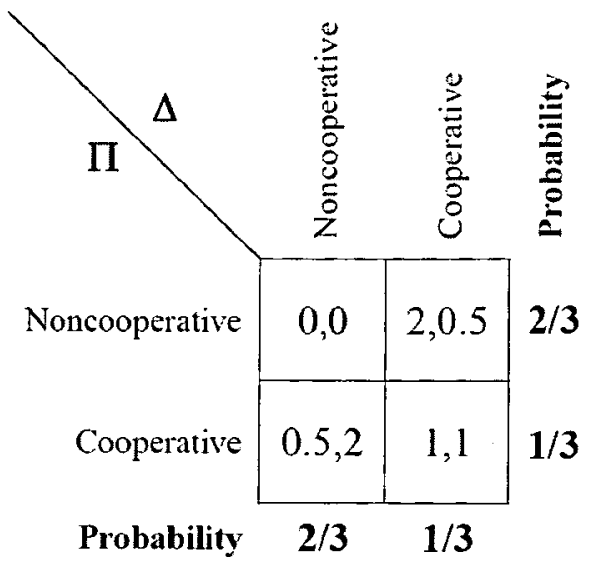

Figure 6b: Distribution of Strategy Pairs in Mixed Strategy Equilibrium

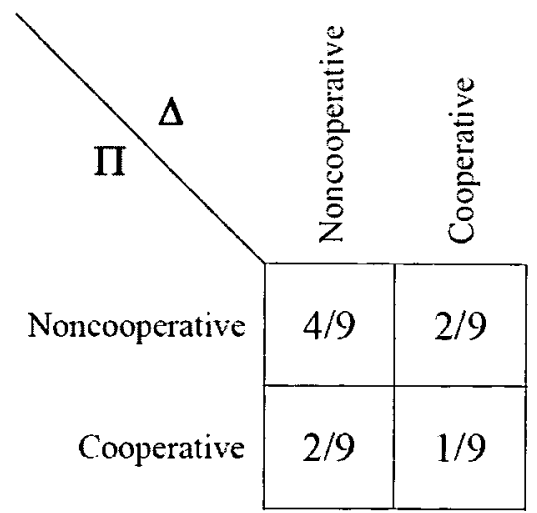

Figure 6a shows that the plaintiff will be mixing its strategies in equilibrium such that it will be noncooperative $2 / 3$ of the time and cooperative $1 / 3$ of the time. The defendant's strategy mix happens to be identical in this example because the matrix is symmetrical. Given the probability weights for each strategy in Figure $6 \mathrm{a}$, Figure $6 \mathrm{~b}$ shows the expected distribution of strategy pairings that will occur during litigation: $4 / 9$ of the time, there will be mutual noncooperation; $2 / 9$ of the time, the plaintiff will cooperate while the defendant will not; $2 / 9$ of the time the defendant will cooperate while the plaintiff will not; and 1/9 of the time, there will be mutual cooperation.

In summary, the "mixed-strategy" Nash equilibrium analysis yields an intuitive model that captures the litigation dynamics with a neutral litigant, whose presence converts discovery from a Prisoner's Dilemma, where noncooperation is the sole optimal strategy, to a different strategic environment where the optimal strategy involves a mix of noncooperation and cooperation. 


\section{Mechanism for NeUtral Litigant Participation}

Part IV analyzes how the neutral litigant described in Part III may be implemented under existing rules and case law. The procedural options are presented, followed by an evaluation of the type of entity that may be suitable for acting in the capacity of a neutral litigant who represents the public interest, and a description of the types of cases that would make best use of this additional litigant.

\section{A. Procedural Issues}

There are two procedural options by which a court could potentially accommodate a neutral litigant who represents the public interest in a patent case: intervention and the "litigating amicus" device. Of the two, the "litigating amicus" device may be a viable option in most cases, whereas intervention may be possible only in very limited circumstances and for a limited purpose.

In the absence of any statutory authority that grants the proposed neutral litigant an unconditional right to intervene ${ }^{162}$ in a given patent case, intervention as of right ${ }^{163}$ is unlikely to be available because the neutral litigant's purpose is not to defend "an interest relating to the property or transaction that is the subject of the action"164-where the "interest" must be "direct, substantial, and legally protectable" 165 - but rather to ensure that the merits of the case are fully and fairly analyzed in light of the public interest. Although some circuits might apply a looser "interest" requirement in public law cases, ${ }^{166}$ patent suits are not presently recognized as a form of "public law" litigation. ${ }^{167}$

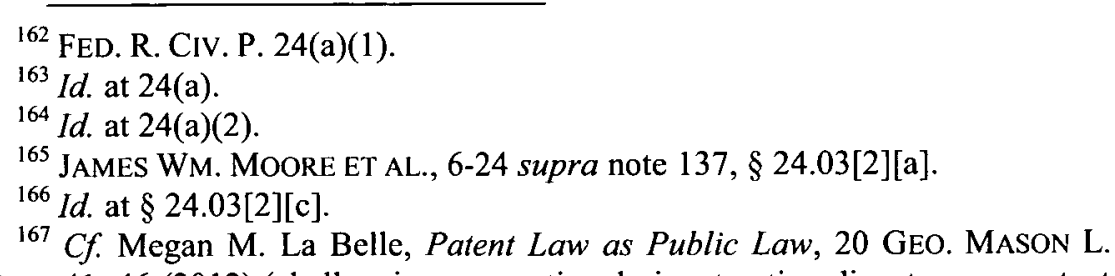
REV. 41, 46 (2012) (challenging conventional view treating disputes over patent validity as private law litigation). Unlike private law litigation, which focuses on redressing disputes between private parties, public law litigation seeks to vindicate the public interest. See id. at 47-49. 
As for permissive intervention, ${ }^{168}$ the neutral litigant might be able to satisfy the requirements under limited circumstances, especially if it is a government agency. Generally, a movant requesting permissive intervention must have either a conditional right to intervene by statute ${ }^{169}$ or a claim involving a common question of law or fact with the action. ${ }^{170}$ If, however, the movant is a government agency, the court may allow intervention if a party's claims or defenses involve a statute or a rule administered by that agency. ${ }^{171}$ For example, because the U.S. Patent and Trademark Office ("PTO") administers the laws governing the issuance of patents (but not enforcement), ${ }^{172}$ a court might allow it to permissively intervene for the specific purpose of addressing an issue relating to patent validity. Similarly, the Federal Trade Commission ("FTC") and the Department of Justice ("DOJ"), both of which administer the antitrust laws, ${ }^{173}$ might be able to permissively intervene to address an antitrust claim raised in a patent case.

As shown by these examples, the scope of permissive intervention may be limited to narrow subject areas, which may hamper the ability of a neutral litigant to fully represent the public interest-and exert a collateral moderating effect on the partiesthroughout the case across a range of issues: procedural matters, patent liability issues, and remedies. A further wrinkle in the utility of permissive intervention is that, although an intervenor

${ }^{168}$ FED. R. CIV. P. 24(b).

${ }^{169} I d$. at $24(\mathrm{~b})(1)(\mathrm{A})$.

${ }^{170} \mathrm{Id}$. at $24(\mathrm{~b})(\mathrm{l})(\mathrm{B})$.

${ }^{171} I d$. at $24(\mathrm{~b})(2)$.

${ }^{172}$ General Information Concerning Patents, U.S. PATENT \& TRADEMARK OFFICE, http://www.uspto.gov/patents/resources/general_info_concerning patents. jsp\# heading-6 (2011) ("The USPTO administers the patent laws as they relate to the granting of patents for inventions .... The USPTO has no jurisdiction over questions of infringement and the enforcement of patents.").

173 About the Bureau of Competition, FED. TRADE COMM'N, http://www.ftc.gov/bc/about.shtm (2013) ("The Federal Trade Commission's Bureau of Competition enforces the nation's antitrust laws . . .."); Mission, U.S. DEP'T OF JUSTICE, ANTITRUST DIV., http://www.justice.gov/atr/about/mission. html ("The mission of the Antitrust Division is to promote economic competition through enforcing and providing guidance on antitrust laws and principles."). 
may continue to litigate through appeal even if the original parties settle, ${ }^{174}$ the intervenor must have Article III standing in order to do so. ${ }^{175}$ Such post-settlement litigation is unlikely to be an option for a neutral litigant who has been granted permissive intervention, as it may have difficulty satisfying the Article III standing requirement.

As an alternative to intervention, the "litigating amicus" device may be suitable for allowing a neutral litigant to substantively participate in all aspects of a patent case. ${ }^{176}$ Unlike a regular amicus, whose participation in a case is generally limited to briefing or oral argument directed to a discrete issue, ${ }^{177}$ a litigating amicus substantively participates in the litigation itself, including

${ }^{174}$ For a neutral litigant who represents the public interest, the ability to continue litigation after the parties settle may be useful in the context of "reverse payments" or "pay-for-delay" settlements in pharmaceutical patent litigation, where a patentee settles a case by paying the generics manufacturer to withdraw its suit challenging patent validity. See generally FTC Resources for Reporters: Pay-for-Delay: When Drug Companies Agree Not to Compete, FED. TRADE COMM'N, http:/www.ftc.gov/opa/reporter/competition/payfordelay.shtml (last visited July 23, 2012) (compiling FTC news releases, reports, and various documents on pay-for-delay issue). Another context where post-settlement litigation may be useful is where the district court grants the parties' joint motion to vacate a non-defective ruling holding a patent invalid, unenforceable, or not infringed in order to facilitate settlement. See generally Jeremy W. Bock, An Empirical Study of Certain Settlement Related Motions for Vacatur in Patent Cases, 88 IND. L. J. 919 (2013) (providing empirical analysis of district courts granting settlement-related vacatur of decisions adverse to patentees).

${ }^{175}$ See Diamond v. Charles, 476 U.S. 54, 68 (1986) ("[A]n intervenor's right to continue a suit in the absence of the party on whose side intervention was permitted is contingent upon a showing by the intervenor that he fulfills the requirements of Art. III.").

${ }^{176}$ Amicus participation is often deemed a fallback position to intervention. JAMES WM. MOORE ET AL., 6-24 supra note 137, § 24.23[2] ("Participation as an amicus curiae, rather than as a party, is appropriate if a person cares about the legal principles that apply to a dispute but has no personal, legally protectable interest in the litigation.").

${ }^{177}$ See Michael K. Lowman, Comment, The Litigating Amicus Curiae: When Does the Party Begin after the Friends Leave?, 41 AM. U. L. REV. 1243, 1245 n.13 (1992) (noting "the traditional roles of brief writing and occasional oral argument" of amicus curiae). 
discovery, motion practice, and trial. ${ }^{178}$ Unlike an intervenor, however, a litigating amicus is unable to appeal from any judgments, and may be dismissed at any time if the court decides that the amicus is no longer necessary. ${ }^{179}$ As with a regular amicus, the decision to allow litigating amicus participation is committed to the discretion of the district court. ${ }^{180}$

The best-known uses of the litigating amicus device occurred in the 1970s and 1980s in highly complex public law cases, such as civil rights litigation. ${ }^{181}$ In those cases, the litigating amicus was often a government entity that had an institutional interest ${ }^{182}$ in participating in the case and had expertise that could assist the

178 See id. at 1246 (collecting cases and noting that "some federal district courts have permitted the amicus to actively engage in oral argument, to introduce physical evidence, to examine witnesses, to conduct discovery, and even to enforce previous court decisions upon party-participants to the litigation").

${ }^{179}$ See 4 AM. JUR. 2D Amicus Curiae $\$ 11$ (2013) ("An amicus curiae has no right to except to the rulings of the court; and if he or she takes such exceptions, they cannot avail on appeal."); John B. Oakley, The United States as Participant in Public Law Litigation: Recent Developments, 13 U.C. DAVIS L. REV. 247, 257 (1980) ("Once intervention is granted, the judge has no more control over the positions taken by the intervenors than over those of the original parties. This is in sharp contrast to the litigating amicus, who serves at the sufferance of the judge and who has no appeal as of right should the judge err.").

${ }^{180}$ See 4 AM. JUR. 2D, supra note $179, \S 1$ ("Although no specific rule permits amicus participation in the trial court, there is no rule prohibiting it, and there is no reason a trial judge should not have discretion to permit such participation if it may be helpful to the court."); $c f$. Gandee v. Glaser, 785 F. Supp. 684, 686 (S.D. Ohio 1992) ("Because the privilege of being heard amicus rests solely within the discretion of the court, it necessarily follows that the scope of the amicus participation must also be discretionary." (citation omitted)).

${ }^{181}$ Linda Sandstrom Simard, An Empirical Study of Amici Curiae in Federal Court: A Fine Balance of Access, Efficiency, and Adversarialism, 27 REV. LITIG. 669, 679 \& n.51 (2008); Lowman, supra note 177, at 1266 (collecting cases).

182 The governmental amici were not necessarily neutral in every case. For example, the DOJ participated in some cases as litigating amici on the side of the plaintiff. See Margo Schlanger, Beyond the Hero Judge: Institutional Reform Litigation as Litigation, 97 MiCH. L. REV. 1994, 2024 (1999) ("In total, prior to 1980, the Department of Justice was either plaintiff, plaintiff-intervenor, or amicus (almost always 'litigating amicus,' participating in discovery, negotiation, and presentation of evidence) in more than ten of the largest and most comprehensive prison cases ... and in a number of jail cases."). 
court in evaluating the impact of a decision on the public at large. ${ }^{183}$ In some instances, district courts have even ordered the government to participate as a litigating amicus. ${ }^{184}$ Although private individuals and organizations have also served as litigating amici, their involvement has been criticized as leaving the case vulnerable to manipulation by a non-party who may attempt to control the litigation in furtherance of its own agenda. ${ }^{185}$

With the possible exception of government amici in complex public law cases, the litigating amicus device is generally viewed

${ }^{183}$ Simard, supra note 181 , at 679 n.51; Lowman, supra note 177 , at 1261-62.

${ }^{184}$ See, e.g., In re Estelle, 516 F.2d 480, 482 (5th Cir. 1975) ("[T] he [district] court ordered the United States to appear in the case as amicus curiae '[i]n order to investigate fully the facts alleged in the prisoners' complaints, to participate in such civil action with the full rights of a party thereto, and to advise [the] court at all stages of the proceedings as to any action deemed appropriate by it." (third and fourth alterations in original)); Oakley, supra note 179, at 255 ("A number of courts faced with massive public law litigation, threatening to exhaust the resources of the original litigants, have permitted, requested and sometimes ordered, the United States to appear as a 'litigating amicus curiae." "); cf. Universal Oil Products Co. v. Root Refining Co., 328 U.S. 575, 581 (1946) ("[A] federal court can always call on law officers of the United States to serve as amici.").

${ }_{185}$ See United States v. Michigan, 940 F.2d 143, 166 (6th Cir. 1991) [hereinafter the Michigan Prisons Case] (characterizing group of private litigants who were granted litigating amicus status as "an intruder with equal litigating rights of a named party/real party in interest, thereby subverting the right of the [named parties] to effectively control the future course of the proceedings"). Perhaps because of the severity of the abuses associated with the private group that had been granted litigating amicus status by the district court, the Sixth Circuit in the Michigan Prisons Case condemned the litigating amicus device in broad, general terms, without distinguishing governmental litigating amici from nongovernmental, private entities. The Michigan Prisons Case is distinguishable where the litigating amicus is a government entity whose expertise is being offered to assist the court without any attempt to take control of the litigation from the named parties. See, e.g., Wyatt v. Hanan, 868 F. Supp. 1356, 1360 (M.D. Ala. 1994) ("Unlike in the Michigan [Prisons] case, this court is not presented with a situation where the amicus curiae is attempting to gain control of the litigation or to prevent its speedy disposition. Rather, the resumption of the federal government's participation in this litigation [as a litigating amicus] will be greatly beneficial to all parties and the court."); see also Lowman, supra note 177, at 1280 ("[U]nlike a governmental party, private parties may have their own agenda, unattached to broad policy goals normally coupled with governmental amici."). 
by district courts as unhelpful: According to one survey conducted in 2007, " $89 \%$ of District Court respondents indicated that litigating amici are a hindrance or a neutral consideration in litigation." "186 This result may be a reflection of the fact that the typical amicus represents partisan interests, ${ }^{187}$ such that judges may be reluctant to confer full litigating privileges, lest the partisan amicus hijack the litigation or unnecessarily complicate or prolong the case in pursuing its own agenda. In addition, for the vast majority of cases on a district judge's docket, the potential benefits of having a litigating amicus may not necessarily outweigh the associated administrative costs. ${ }^{188}$

Indeed, where district courts have used litigating amici in the past, it tended to be in highly complex cases that had strong public interest consequences, ${ }^{189}$ in which the participation of the litigating amici would likely provide a net benefit. For this reason, litigating amici may be particularly suitable for patent cases given their complexity ${ }^{190}$ and the public interest inherent in the fair, accurate, efficient, and just resolution of the dispute. ${ }^{191}$

\section{B. Choice of Neutral Litigant}

As discussed in the preceding section, the most viable path for introducing a neutral litigant into a patent case may be through the litigating amicus device, where the litigating amicus is a government entity whose purpose in participating in the case is to provide the court with a disinterested analysis of the merits that is informed by its participation in discovery, its impartial evaluation of the facts and the law, and its assessment of the public interest.

\footnotetext{
${ }^{186}$ Simard, supra note 181 , at 694.

187 See id. at 676 ("Over time, amici curiae evolved into third party representatives, less concerned with providing unbiased scholarly guidance to the court and more interested in protecting the interests of individuals or entities who were not named parties in a suit.").

${ }^{188}$ For a discussion of the administrative costs of the litigating amicus, see infra Part IV.C.

${ }_{189}^{189}$ See supra notes 181-184 and accompanying text.

${ }^{190}$ See supra notes $12-13$ and accompanying text.

191 See supra notes 1-2 and accompanying text.
} 
Some may argue, however, that the neutral litigant function could be assumed by a special master whose duties are extended to include active participation in discovery and motion practice. This is a suboptimal arrangement because an individual special master does not have the resources of a government agency to participate effectively in all aspects of the litigation for the full duration of the case, which could be several years. Furthermore, because of the level of participation required, a special master-who is compensated by the parties pursuant to a court order or from funds controlled by the court ${ }^{192}$ - may be hindered in his ability to take on additional engagements. As a result, the economic interests of the special master may leave him vulnerable to influence by the parties or the court, so as to adversely affect the manner in which he executes his duties as a neutral litigant who is charged with representing the public interest.

More generally, private entities, including public interest groups, may be poor choices for a neutral litigant. ${ }^{193}$ For example, organizations such as the American Civil Liberties Union ("ACLU"), ${ }^{194}$ the Electronic Frontier Foundation ("EFF"), ${ }^{195}$ and Public Knowledge ${ }^{196}$ are likely to align themselves with the accused infringer throughout the case, rather than providing an impartial, disinterested analysis of the merits. As discussed previously, the collateral moderating effect is unlikely to exist if the neutral litigant is perceived as having an agenda that is strongly aligned with or against one of the parties. ${ }^{197}$

Given the concerns with private entities, the neutral litigant function may be best served by a government entity. Ideally, it would be an existing agency whose mission would be furthered by its participation in a patent case. The neutral litigant role may be

${ }^{192}$ FED. R. CIV. P. 53(g)(2).

${ }^{193}$ See supra notes $185-187$ and accompanying text.

194 AMERICAN CIVIL LIBERTIES UNION, http://www.aclu.org/ (last visited Oct. 13, 2013).

i95 Electronic Frontier Foundation, https://www.eff.org/ (last visited Oct. 13, 2013).

196 PubliC KNOWLEDGE, http://publicknowledge.org/ (last visited Oct. 13, 2013).

${ }^{197}$ See supra Part III.B. 
fulfilled by one or more staff members at the agency, such as an attorney who has experience in patent litigation and a staff economist who can assist with issues related to remedies. Because impartiality is a critical trait of the neutral litigant, ${ }^{198}$ the agency should be insulated from, or at least be highly resistant to, pressure from the legislative and executive branches, including other agencies.

In view of the considerations listed above, the Federal Trade Commission ("FTC") may be the best choice among existing government agencies to serve as a neutral litigant in district court patent litigation. The FTC's interest and expertise in evaluating the intersection between patent policy and the public interest are well-documented. For example, the FTC issued authoritative reports in $2003^{199}$ and $2011^{200}$ analyzing innovation policy and providing recommendations on the proper balance between patents and competition, and, most recently, the FTC has announced its intention to study the practices of patent assertion entities. ${ }^{201}$ The FTC also files amicus briefs and provides comments in high profile patent cases. ${ }^{202}$ In addition, pursuant to its mandate to investigate "unfair methods of competition" under Section 5 of the FTC $\mathrm{Act}^{203}$ - which may extend to activities beyond the reach of

${ }^{198}$ See supra Part III.B.

199 Fed. Trade Comm'n, To Promote Innovation: The Proper Balance of COMPETITION AND PATENT LAW AND POLICY (2003), available at http://www.ftc.gov/os/2003/10/innovationrpt.pdf.

200 Fed. Trade Comm'N, The Evolving IP Marketplace: Aligning PATENT Notice AND REMEDIES WITH COMPETITION (2011), available at Www.ftc.gov/os/2011/03/110307patentreport.pdf.

201 FTC Seeks to Examine Patent Assertion Entities and Their Impact on Innovation, Competition, FED. TRADE COMM'N (Sept. 27, 2013) http://www.ftc.gov/opa/2013/09/paestudy.shtm (press release announcing study of patent assertion entities).

202 See Advocacy Filings by Subject: Intellectual Property, FED. TRADE COMM'N, http://www.ftc.gov/opp/advocacy_subject.shtm\#iptg (last visited Oct. 7,2013 ) (listing advocacy filings).

${ }^{203}$ Section 5 of the FTC Act, codified at 15 U.S.C. $\S 45$ (2006), provides in pertinent part:

$\S 45$. Unfair methods of competition unlawful; prevention by Commission 
antitrust law ${ }^{204}$ - the FTC has investigated anticompetitive practices involving patents. For example, the FTC has been actively involved in suits ${ }^{205}$ challenging "reverse payment" settlements in pharmaceutical patent cases. ${ }^{206}$ It has also used its Section 5 enforcement powers to investigate the patent holdup problem in the standard-setting context. ${ }^{207}$ Based on the FTC's willingness to study and investigate matters relating to the impact of various patent enforcement activities on the public interest, having the FTC serve as a neutral litigant may enhance its mission by allowing it to participate directly in a broader set of patent cases - such as those involving patent assertion entities (or "patent

(a) Declaration of unlawfulness; power to prohibit unfair practices; inapplicability to foreign trade

(1) Unfair methods of competition in or affecting commerce, and unfair or deceptive acts or practices in or affecting commerce, are hereby declared unlawful.

(2) The Commission is hereby empowered and directed to prevent persons, partnerships, or corporations . . from using unfair methods of competition in or affecting commerce and unfair or deceptive acts or practices in or affecting commerce.

Id. Notably, the FTC's mandate under Section 5 bears some similarity to the ITC's mandate under Section 337 to investigate "unfair methods of competition" and "unfair acts" arising in the context of importation. Compare 19 U.S.C. $\S 1337$ (a) (2006) with 15 U.S.C. § 45(a)(1) (2006).

${ }^{204}$ See D. Daniel Sokol, Antitrust, Institutions, and Merger Control, 17 GEO. MASON L. REV. 1055, 1079 (2010) ("An expansive reading of Section 5 allows the FTC to prohibit conduct that the DOJ cannot. It does so with language that might take on non-economic justifications, as in prohibiting conduct that is 'unjust,' 'oppressive,' or 'immoral.'"); see also Neil W. Averitt, The Meaning of "Unfair Methods of Competition" in Section 5 of the Federal Trade Commission Act, 21 B.C. L. REV. 227, 235 (1980) (reviewing legislative history).

${ }^{205}$ See, e.g., FTC v. Actavis, Inc., 133 S. Ct. 2223 (2013); Schering-Plough Corp. v. FTC, 402 F.3d 1056 (1lth Cir. 2005); FTC v. Cephalon, Inc., No. 1:08-cv-00244 (D.D.C Feb. 13, 2008).

${ }^{206}$ See supra note 174.

${ }^{207}$ See, e.g., Negotiated Data Solutions LLC, File No. 051-0094, 2008 WL 258308 (F.T.C. Jan. 22, 2008); Complaint, Union Oil Co. of Cal., File No. 011-0214, Docket No. 9305, 2003 WL 1190102 (F.T.C. Mar. 4, 2003); Complaint, Rambus Inc., File No. 011-0017, Docket No. 9302, 2002 WL 1436415 (F.T.C. June 18, 2002); Dell Computer Corp., 121 F.T.C. 616 (1996). 
trolls") ${ }^{208}$ - that may benefit from its expertise but which might lie beyond its enforcement powers under Section 5 or the antitrust laws.

A possible objection to the FTC serving as a neutral litigant might be that its presence could hinder discovery because one or both parties may be concerned about producing confidential information that could provide grounds for a future FTC enforcement action. In view of these concerns, the court can require the FTC to establish an ethical wall separating the staff serving as neutral litigants from the staff responsible for enforcement actions. Furthermore, as a neutral litigant, the FTC, like the named parties, would be subject to a protective order that would limit the FTC's use of any confidential information that was produced during a given case for purposes of that litigation only.

Other than the FTC, the DOJ or the PTO could also potentially serve as neutral litigants, but they are less preferable choices. Both the DOJ and the PTO have personnel who are experienced in litigating patent-related issues: The DOJ's commercial litigation branch has an intellectual property section that defends the United States government in patent cases, ${ }^{209}$ and the PTO's Office of the Solicitor defends decisions of the Patent Trial \& Appeal Board in federal court. ${ }^{210}$ However, the DOJ and the PTO may be more susceptible to political influence than the FTC, which is an independent agency. ${ }^{211}$ The DOJ, for example, changed its position

${ }^{208}$ Cf. J. Thomas Rosch, Comm'r, Fed. Trade Comm'n, Patent Trolls: Broad Brush Definitions and Law Enforcement Ideas, Remarks Before the Newport Summit on Antitrust \& Economics 11-14 (May 31, 2008), available at http://www.ftc.gov/speeches/rosch/080531 roschlecg.pdf (discussing potential theories for bringing Section 5 actions against patent trolls and noting potential difficulties).

${ }^{209}$ Commercial Litigation Branch, Intellectual Property Section, U.S. DEP'T OF JUSTICE, http://www.justice.gov/civil/commercial/intellectual/c-ip.html (last visited July 10, 2012).

210 Office of the Solicitor, U.S. PATENT \& TRADEMARK OfFICE, http://www.uspto.gov/ip/boards/solicitor/index.jsp (last visited July 10, 2012).

${ }^{211}$ See Sokol, supra note 204, at 1074-75 ("Overall, the literature on agencies suggests that independent agencies are better suited to dealing with both time consistency and credible commitment problems. Such advantages exist because 
regarding the legality of reverse payments when the administration changed: During the presidency of George W. Bush, the DOJ was unwilling to join the FTC's position that "reverse payment" settlements in pharmaceutical patent cases $^{212}$ were presumptively illegal, whereas early in the Obama administration, the DOJ changed its position and aligned itself with the FTC. ${ }^{213}$ As for the PTO, it has been accused of succumbing to lobbying efforts by the Canadian government on behalf of BlackBerry ${ }^{\circledR}$ maker Research in Motion, Ltd. ("RIM") in its alleged special treatment of the reexamination of NTP, Inc.'s patents that were found to have been infringed by RIM. ${ }^{214}$

The ability of the neutral litigant to resist political pressure is critical because the circumstances under which political considerations might creep into the neutral litigant's work would be in its analysis of close questions, novel issues, ${ }^{215}$ or public interest considerations ${ }^{216}$ — which may be outcome-determinative in some cases. Because the type of patent case for which a neutral

independent agencies are more insulated from political pressures and less likely to succumb to the majoritarian impulse of unpopular decisions.").

${ }^{212}$ See supra note 174.

${ }^{213}$ See, e.g., Steven Seidenberg, The Flip Side of 'Reverse Payments,' A.B.A. J. (Feb 1, 2010, 4:00 AM), http://www.abajournal.com/magazine/article/ the_flip_side_of_reverse_payments (observing change in DOJ position on reverse payments). The DOJ's change in position appears to have been a direct result of an Obama appointee heading the Antitrust Division. $C f$. James J. O'Connell, Second Bites and the Search for a Standard: The DOJ's Cipro Brief, 24 ANTITRUST ABA 7, 8 (2010) ("[D]uring her confirmation hearing before the Senate Judiciary Committee, Christine Varney-a former FTC commissioner herself and President Obama's nominee to be Assistant Attorney General in charge of the [DOJ] Antitrust Division-pledged to 'work with the Department of Justice to align the Federal Trade Commission and the DOJ on the reverse payment issue." (citation omitted)).

214 Yuki Noguchi, Canada Lobbies for Maker of BlackBerry, WASH. POST (Feb. 22, 2006), http://www.washingtonpost.com/wp-dyn/content/article/ 2006/02/21/AR2006022101711_pf.html.

215 The recently-enacted Leahy-Smith America Invents Act, 112 Pub. L. No. 112-29, 125 Stat. 284 (2011), will likely raise many issues of statutory interpretation over the next couple of decades.

${ }^{216}$ For example, the traditional four-factor test for injunctions contains a public interest factor. See eBay Inc. v. MercExchange, L.L.C., 547 U.S. 388, 391 (2006). 
litigant is most needed will be the largest, most complex ones ${ }^{217}$ involving well-heeled parties who likely possess the resources not only to engage in highly-contentious, protracted litigation, but also to exert political pressure, it is critical that the neutral litigant be insulated from political influence as much as possible in order to preserve its impartiality-which, as discussed previously, is one of the key traits that renders the neutral litigant's views persuasive to the court and allows it to exert a moderating influence on the parties' tendency to engage in hyper-contentious advocacy. ${ }^{218}$

In addition, where a government agency serves as a neutral litigant, the institutional responsibilities of that agency will likely color its public interest analysis. For example, the DOJ's mission is to advance the interests of the federal government, ${ }^{219}$ which includes the enforcement and defense of duly-enacted federal laws from legal challenges-including certain laws that may not fully serve the public interest. ${ }^{220}$ In matters involving patents, the DOJ will often coordinate its positions with the applicable "client" agency, ${ }^{221}$ namely, the $\mathrm{PTO},{ }^{222}$ which is routinely listed as

${ }^{217}$ See infra Part IV.C.

${ }^{218}$ See supra Part III.B.

${ }^{219}$ The DOJ's mission statement is as follows:

To enforce the law and defend the interests of the United States according to the law; to ensure public safety against threats foreign and domestic; to provide federal leadership in preventing and controlling crime; to seek just punishment for those guilty of unlawful behavior; and to ensure fair and impartial administration of justice for all Americans.

About DOJ, U.S. DEP'T OF JUSTICE, http://www.justice.gov/about/about.html (last visited Oct. 27, 2013).

${ }^{220}$ For example, the DOJ defended the Defense of Marriage Act (DOMA), which barred federal recognition of same-sex marriages, until 2011 when President Barack Obama directed the DOJ to stop defending it in court. U.S. DeP'T OF Justice, STATEMENT OF THE ATtORNEy General on Litigation INVOLVING THE DEFENSE OF MARRIAGE ACT (Feb. 23, 2011), available at http://www.justice.gov/opa/pr/2011/February/11-ag-222.html; Charlie Savage \& Sheryl Gay Stolberg, In Turnabout, U.S. Says Marriage Act Blocks Gay Rights N.Y. TIMES, Feb. 24, 2011, at Al (providing analysis of DOJ's position and president's order).

${ }^{221}$ See Neal Devins \& Michael Herz, The Uneasy Case for Department of Justice Control of Federal Litigation, 5 U. PA. J. CoNST. L. 558, 580-81 (2003) ("[T]he agency is a captive client; it cannot choose to use its own lawyers or 
co-counsel on the DOJ's amicus briefs (and vice versa) filed in patent cases at the Federal Circuit and at the Supreme Court. ${ }^{223}$ The PTO, in turn, has "clients" of its own in the form of patent owners and applicants, ${ }^{224}$ whose user fees completely fund its operation. ${ }^{225}$ Furthermore, the PTO has a "symbiotic" relationship

retain a different 'firm.' . . . DOJ's stance has generally been one of grudging acknowledgment that the agencies have the primary policymaking responsibilities.").

${ }^{222}$ See The USPTO: Who We Are, U.S. PATENT \& TRADEMARK OfFICE, http://www.uspto.gov/about/index.jsp (last visited Oct. 27, 2013) ("The USPTO advises the President of the United States, the Secretary of Commerce, and U.S. Government agencies on intellectual property (IP) policy, protection, and enforcement ....").

${ }^{223}$ See, e.g., Brief for the United States as Amicus Curiae Supporting Neither Party, Mayo Collaborative Servs. v. Prometheus Labs., Inc., 132 S. Ct. 1289 (2012) (No. 10-1150), $2011 \mathrm{WL}$ 4040414; Brief for the United States as Amicus Curiae Supporting Respondents, Microsoft Corp. v. i4i Ltd. P'ship, 131 S. Ct. 2238 (2011) (No. 10-290), 2011 WL 991991; Brief for the United States as Amicus Curiae on Rehearing En Banc in Support of Neither Party, Therasense, Inc. v. Becton, Dickinson \& Co., 649 F.3d 1276 (Fed. Cir. 2011) (Nos. 08-1511, 1512, 1513, 1514, 1595), 2010 WL 3390234; Brief for the United States as Amicus Curiae on Rehearing En Banc in Support of Respondent, Ariad Pharms., Inc., v..Eli Lilly \& Co., 598 F.3d 1336 (Fed. Cir. 2010) (No. 08-128), 2009 WL 4832140 .

A rare but notable divergence between the PTO and the DOJ occurred on the issue of genes as patentable subject matter. See Andrew Pollack, Patent Protection, Breached, N.Y. TIMES, at B1 (Nov. 2, 2010) ("The patent office appears to have opposed the position taken in the Justice Department's brief. None of its lawyers were listed as authors.").

${ }^{224}$ Arti K. Rai, Engaging Facts and Policy: A Multi-Institutional Approach to Patent System Reform, 103 COLUM. L. REV. 1035, 1133 (2003) ("[T]he PTO appears to have developed an institutional culture that treats patentees as 'clients' to be served rather than as claimants who must present a case for being entitled to a patent.").

${ }^{225}$ U.S. Patent \& Trademark Office, Fiscal Year 2013 President's BUDGET 5 (Feb. 13, 2012), available at http://www.uspto.gov/about/ stratplan/budget/fy13pbr.pdf ("As a fully user-fee funded organization, the USPTO is able to complete its mission with zero net discretionary spending and at no cost to the taxpayer."); see also Stuart Minor Benjamin \& Arti K. Rai, Who's Afraid of the APA? What the Patent System Can Learn from Administrative Law, 95 GEO. L.J. 269, 314 (2007) ("[T]he problem of capture arises with respect to the PTO . . . It is favorably disposed to patent holders. Not only is the incentive system of individual examiners strongly tilted towards granting patents, but the agency as a whole is funded by applicant fees."). 
with the patent bar. ${ }^{226}$ Accordingly, if the DOJ and/or the PTO were to serve as the neutral litigant, the interests of their respective "clients" may substantially influence ${ }^{227}$ their positions in the case. In contrast, the FTC, whose institutional responsibilities are directed to protecting consumers and competition, ${ }^{228}$ does not have "client" agencies like the DOJ, or a user base whose fees fully fund its operations like the PTO. As a result, at least compared to the DOJ and the PTO, the FTC's public interest analysis in its role as a neutral litigant may be less susceptible to undue influence from other agencies or third parties.

Some may question the FTC's suitability as a neutral litigant because they view the agency as being possibly biased against

${ }^{226}$ Cecil D. Quillen, Jr., the former General Counsel of Eastman Kodak Co., described the "symbiotic" relationship between the PTO and patent attorneys as follows:

There has long been a symbiotic relationship between the Patent Office and those who practice before it, and those who litigate its results. Each has depended on the other for their livelihoods. Historically the way it worked was that the Patent Office would issue a few more patents each year, which would require a few more patent applications, which would require a few more patent attorneys and patent examiners, and on and on and on. These steady increases in the numbers of patents and patent applications, and the consequent growth in the need for more examiners and more patent attorneys, assured job security and attractive incomes for both, and also assured that neither had the slightest interest in changing the system.

Cecil D. Quillen, JR., The U.S. Patent System: Is it Broke? And Who Can FIX IT IF IT Is?, at 17 (May 11, 2001), available at http://www.ftc.gov/os/ comments/intelpropertycomments/quillenattachments/isitbrokewhocanfixit.pdf (presenting remarks at the Spring Meeting of the Association of General Counsel).

227 See generally Jonathan S. Masur, The PTO's Future: Reform or Abolition?, 158 U. PA. L. REV. PENNumBrA 1, 6-8 (2009) (describing how PTO's "clients" have lobbied for or against the PTO on certain issues, such as funding and rulemaking, and noting possible proxy war and factionalism among "clients").

${ }^{228}$ The FTC's mission statement is as follows: "To prevent business practices that are anticompetitive or deceptive or unfair to consumers; to enhance informed consumer choice and public understanding of the competitive process; and to accomplish this without unduly burdening legitimate business activity." About the Federal Trade Commission, FED. TRADE COMM'N, http://www.ftc.gov/ftc/about.shtm (last visited Oct. 27, 2013). 
patentees, especially given its litigation against reverse payments ${ }^{229}$ and enforcement actions against companies that have abused the standard setting process. ${ }^{230}$ Viewed fairly, however, these activities reflect the FTC's interest in maintaining a balance between patent law and competition pursuant to its mandate under the antitrust laws and the FTC Act, ${ }^{231}$ rather than an institutional hostility toward patentees. Moreover, many of the positions taken by the FTC on patent-related issues are similar to those taken by the DOJ and the PTO. Indeed, the FTC and the DOJ have collaborated on a report analyzing the interface between antitrust and intellectual property ${ }^{232}$ and have held a joint workshop on patent assertion entities. $^{233}$ In addition, all three agencies have recently taken similar positions on the remedies appropriate for standards-essential patents. ${ }^{234}$

\section{Case Selection and Cost}

In the 12-month period ending March 31, 2012, over 4,000 patent cases were filed in the federal district courts. ${ }^{235}$ As such, it would not be practicable for every district court patent case to

${ }^{229}$ See supra note 205 and accompanying text.

${ }^{230}$ See supra note 207 and accompanying text.

${ }^{231}$ See supra notes 203 and 228 and accompanying text.

${ }^{232}$ U.S. DEP'T OF JUSTICE \& FED. TRADE COMM'N, ANTITRUST ENFORCEMENT AND InTEllectual Property Rights: Promoting InNOVATION AND COMPETITION (Apr. 2007), available at http://www.ftc.gov/reports/innovation/ P040101PromotingInnovationandCompetitionrpt0704.pdf.

${ }^{233}$ Patent Assertion Entity Activities Workshop, U.S. DEP'T OF JUSTICE \& FED. TRADE COMM'N, (Dec. 2012), http://www.ftc.gov/opp/workshops/pae/.

${ }^{234}$ Compare U.S. Dep'T OF Justice \& U.S. Patent \& TRademark Office, Policy STATEMENT ON REMEdes fOR STANDARds-Essential Patents SubJECT TO VOLUNTARY F/RAND COMMITMENTS, (Jan. 2013), http://www.justice.gov/atr/public/guidelines/290994.pdf, with Motorola Mobility LLC and Google Inc., FTC File No. 121-0120, (Jan. 3, 2013), 2013 WL 124100, available at http://www.ftc.gov/os/caselist/1210120/130103 googlemotorolado.pdf.

${ }_{235}$ U.S. Courts, Table C-2, U.S. District Courts-Civil Cases COMMENCED, By BASIS OF JURISDICTION AND NATURE OF SUIT, DURING THE 12-MONTH PERIODS ENDING MAR. 31, 2011 AND 2012 (2012), http://www.uscourts.gov/Viewer.aspx?doc=/uscourts/Statistics/FederalJudicialC aseloadStatistics/2012/tables/C02Mar12.pdf (noting that 4,446 patent cases were filed). 
include a neutral litigant from a government agency. Accordingly, whether a given patent case would merit participation by a neutral litigant needs to be analyzed from a cost-justification standpoint. Even the ITC, where only forty Section 337 investigations were initiated in $2012,{ }^{236}$ recently decided to assign an ITC staff attorney to only a subset of the investigations (instead of every one of them) in light of budget constraints. ${ }^{237}$

In selecting district court patent cases for neutral litigant participation, one criterion may be the complexity of the case, as measured by the number of parties, asserted patents, or related cases involving the same patent. In such cases, having a neutral litigant who participates in all aspects of the litigation would be particularly useful in streamlining the number of issues that require adjudication. ${ }^{238}$ A supplemental or alternative criterion could be the economic "footprint" of the case based on the size of the potential market, including upstream markets (e.g., the accused infringer's suppliers) and downstream markets (e.g., the accused infringer's customers and end-users), that may be materially affected by the outcome of the litigation. If a case has a large economic footprint, such that the outcome may have substantial effects on third parties, the highly-polarized arguments proffered by the parties on contested issues may not be sufficient to ensure a just outcome-or, at the very least, make it difficult for the court to achieve it. In such circumstances, a neutral litigant who represents the public interest may help enhance the court's ability to adjudicate both accurately and fairly by providing a disinterested analysis and highlighting public interest considerations where appropriate.

More generally, having a threshold based on the complexity of the case or its economic footprint (or both) is necessary because, in accommodating a neutral litigant, various administrative costs may be imposed on the court, the parties, and the government agency serving as the neutral litigant. For the court, the administrative

236 See supra note 99.

${ }^{237}$ See Davis, supra note 91. The effect of the decreased participation of the ITC staff attorney on Section 337 actions may be evaluated in future research.

${ }^{238}$ See supra Part III.B. 
cost would primarily take the form of reviewing an additional brief-i.e., the neutral litigant's views and responses to the parties-for each motion ${ }^{239}$ or required submission (e.g., claim construction briefing). For the parties, the administrative costs would take the form of responding to the neutral litigant's briefs, responding to the neutral litigant's discovery requests that are not duplicative of the opposing party's requests, and accommodating the neutral litigant's schedule when scheduling depositions, meetings, or hearings. For the government agency serving as the neutral litigant, the administrative cost would be the commitment of personnel to the neutral litigant role. In order to maintain the impartiality and the independence of the neutral litigant, the government agency that acts as the neutral litigant should not be compensated by the court or the parties for undertaking that role.

For patent cases that meet the complexity and/or economic footprint thresholds, the benefits associated with the neutral litigant's disinterested analysis of the merits and the streamlining of issues resulting from the collateral moderating effect ${ }^{240}$ are expected to outweigh the associated administrative costs. For the court, the amount of work involved in reviewing the extra briefs filed by the neutral litigant would be offset by the decrease in the aggregate number of motions filed by the parties, greater selectivity in the issues raised in the motions that do get filed, and more refined arguments presented by the parties in support of their positions. ${ }^{241}$ In addition, the disinterested analysis provided by a neutral litigant may enhance the district court's ability to adjudicate accurately, thereby potentially increasing the chances of an affirmance on appeal. ${ }^{242}$ For the parties, they would have the

${ }^{239}$ Based on the Author's experiences in ITC litigation, if the neutral litigant is modeled after the ITC staff attorney, it will rarely file motions, and most of its substantive filings will be responses to the parties' submissions.

${ }^{240}$ See supra Part III.B.

${ }^{241}$ See id.supra Part III.B.

${ }^{242}$ In assessing the impact of a neutral litigant on the accuracy of adjudication, it may be helpful to consider the data from an empirical study of special masters in district court patent cases, as both neutral litigants and special masters are impartial and would have specialized expertise in patent litigation. According to a study by Kesan and Ball for the Federal Judicial Center, "[t]he appeal rate among cases in which special masters were employed was comparable to that of 
benefit of streamlined motion practice as well as fewer unproductive fights over discovery, scheduling, and administrative issues because of the collateral moderating effect. ${ }^{243}$ Also, patent litigators who are familiar with ITC practice should not have any difficulty adapting to the presence of a neutral litigant who plays a role in district court cases that is similar to that of the ITC staff attorney in Section 337 actions. And for the government agency acting as the neutral litigant, participating in only the most complex, high-stakes matters allows the agency to be directly involved in those cases that are likely to have a significant impact on the development of the law.

Some may contend, however, that the presence of a neutral litigant might aggravate the tensions between the parties and increase the complexity of the case by pointing to child custody litigation. There, a three-sided litigation environment created by the participation of a guardian ad litem appointed by the court to

the total population of patent cases, as was the reversal rate," see KESAN \& BALL, supra note 132, at 12, but that in "complex" patent cases, which are defined as those lasting longer than 1,000 days, id . at 10 , "[t]he appeal rate among cases in which special masters were employed was half that of other complex patent cases" and "[t]he reversal rate [was] also lower for patent cases with special masters when compared to the reversal rate for all complex patent cases." Id. at 13 .

A study also exists that compares the claim construction reversal rate between the ITC and the district courts, which analyzes whether the specialized expertise of the ITC ALJS and the participation of the ITC staff attorneys result in a lower reversal rate than the generalist district courts. David L. Schwartz, Courting Specialization: An Empirical Study of Claim Construction Comparing Patent Litigation Before Federal District Courts and the International Trade Commission, 50 WM. \& MARY L. REV. 1699, 1699 (2009). Although this study found that the reversal rate was comparable, id. at 1716, Table II, it may not necessarily be indicative of an apples-to-apples comparison, $i d$. at 1720 , from which the impact of the ITC staff attorney on adjudication accuracy may be conclusively determined. Rather, to evaluate whether the ITC staff attorney's participation improves accuracy, it is necessary to compare ITC investigations that involve an ITC staff attorney with those that do not. See supra text accompanying notes 99-100.

${ }^{243}$ See supra Part III.B. 
represent the "best interests of the child"244 may, in some instances, actually increase the contentiousness of the proceeding ${ }^{245}$ if one or both parents treat the guardian ad litem with suspicion ${ }^{246}$ or outright hostility. ${ }^{247}$

That the presence of a neutral litigant might exacerbate the adversarial atmosphere in child custody cases, while having a moderating effect in patent litigation at the ITC and in Supreme Court practice, ${ }^{248}$ suggests that the beneficial effects of the neutral litigant may be further limited to certain types of subject matter or parties. Child custody disputes are one of the most emotionallycharged matters handled by courts, ${ }^{249}$ and, in a large percentage of them, at least one parent may not be represented by counsel. ${ }^{250}$ The

${ }^{244}$ See, e.g., Marcia M. Boumil et al., Legal and Ethical Issues Confronting Guardian ad litem Practice, 13 J.L. \& FAM. STUD. 43, 43-44 (2011) ("A guardian ad litem ("GAL") is an individual appointed by the court to serve as an independent advocate who promotes the best interests of minors, elders, and legally incompetent persons in custody disputes, abuse and neglect cases, guardianships, and other court proceedings. GALs generally have expertise as lawyers, mental health professionals or both.").

${ }^{245}$ See Barbara Ann Atwood, Representing Children: The Ongoing Search for Clear and Workable Standards, 19 J. AM. ACAD. MATRIM. LAW 183, 210 (2005) ("Recognizing that children's lawyers and guardians ad litem could easily exacerbate the adversarial atmosphere as well as the cost of divorce litigation, the AAML [American Academy of Matrimonial Lawyers] recommends that courts make specific findings in any case as to why an appointment is appropriate.").

${ }^{246}$ See, e.g., Mary Grams, Guardians Ad Litem and the Cycle of Domestic Violence: How the Recommendations Turn, 22 LAW \& INEQ. 105, 105 (2004) ("While judicial officials applaud the work done by guardians ad litem, many parents and lawyers view guardians as biased spies who selectively report their findings for rubber-stamping by an overworked judiciary.").

${ }^{247}$ In some cases, guardians ad litem have been threatened with lawsuits or even violence. See Boumil, supra note 244, at 77-78.

${ }^{248}$ See supra Part III.A.

${ }^{249}$ See, e.g., Viamonte v. Viamonte, 748 A.2d 493, 498 (Md. App. 2000) ("Child custody cases are among the most emotionally charged matters to come before the trial court....").

${ }^{250}$ See Steven K. Berenson, A Family Law Residency Program?: A Modest Proposal in Response to the Burdens Created by Self-Represented Litigants in Family Court, 33 RUTGERS L.J. 105, 110 (2001) ("[T] he percentage of cases in which one or both of the parties appears without a lawyer is significantly higher in family law cases than in any other area of the law. . . [A] California Bar 
emotionally-charged subject matter coupled with the high incidence of pro se litigants may render child custody disputes a highly volatile litigation environment where the presence of a neutral litigant may not necessarily exert a salutary effect on the overall level of contentiousness. In contrast, patent litigationwhether in the ITC or in the district court-usually involves business entities or organizations that are represented by counsel, ${ }^{251}$ and the subject matter is less emotionally-charged than family law, such that the collateral moderating effect arising from the neutral litigant's presence in ITC patent litigation is also likely to occur in district court patent litigation.

\section{General ObJections and Concerns}

In the previous sections, various specific objections and concerns were addressed as the context arose. There are, however, three general objections and concerns directed to the concept of the neutral litigant that are worth highlighting and addressing separately: (1) ensuring the neutral litigant's neutrality; (2) funding issues and resource constraints; and (3) the impact on the adversary system.

Ensuring Neutrality. The ability of the neutral litigant to remain impartial is a critical concern. There are several means for minimizing the likelihood that the neutral litigant would somehow become beholden to or unduly influenced by the court or the parties, as well as mitigating any biases that the neutral litigant may have. First, there would be no ex parte communications between the court and the neutral litigant, ${ }^{252}$ in order to prevent the neutral litigant from being unduly influenced by the court (or vice

Report based on 1991 and 1995 data indicated that at least one party appeared without a lawyer in $67 \%$ of all domestic relations cases and in $40 \%$ of all child custody cases.").

${ }^{251}$ According to a study of "high-tech" patent suits filed between 2000-2008, only $5 \%$ of the suits were initiated by individuals. Colleen V. Chien, Of Trolls, Davids, Goliaths, and Kings: Narratives and Evidence in the Litigation of HighTech Patents, 87 N.C. L. REv. 1571, 1600 \& Table 3 (2009). Any individuals who can afford to litigate a patent dispute are likely sophisticated enough to hire counsel.

${ }^{252}$ See supra Part III.B. 
versa). Second, a government agency should serve as the neutral litigant, instead of a private individual who will need to be compensated by the court or the parties. ${ }^{253}$ In addition, public interest groups may be unsuitable because they are likely to pursue an agenda on intellectual property issues that may be strongly aligned with or against one of the parties. ${ }^{254}$ Third, the neutral litigant would set forth its views and responses to the parties' filings on an issue-by-issue basis (which is how the ITC staff attorney provides its views to the ALJ). ${ }^{255}$ For example, if there are multiple claim terms requiring construction, the neutral litigant would provide its views for each term, which may favor one party on some terms, the other party on different terms, and neither party on the remaining terms. Fourth, the government agency acting as the neutral litigant will likely have an institutional interest in cultivating a reputation for impartiality in order to enhance its credibility with the court, which may help restrain or suppress any partisan inclinations that the agency might exhibit otherwise. And finally, if the neutral litigant participates in the case through the litigating amicus device, the court has considerable discretion to define the scope of the neutral litigant's activities and may even dismiss the neutral litigant if its analysis appears to be biased and thus insufficiently useful to the court to justify the administrative costs associated with its participation in the case. ${ }^{256}$

Funding Issues and Resource Constraints. Another concern relates to how this proposal would be funded. Because the government agency that participates as a neutral litigant in a given case will do so at its own expense, it is critical that the neutral litigant be furnished by an agency that would have a strong interest in participating in patent cases as a means of furthering its mission. As discussed previously, one of the agencies that might be particularly suitable is the FTC, which is actively involved in litigation, research, and advocacy concerning patent-related issues and the public interest. ${ }^{257}$ As such, the FTC's participation in

\footnotetext{
${ }^{253}$ See FED. R. CIV. P. 53(g)(2).

${ }^{254}$ See supra text accompanying notes 193-197.

255 See supra note 77 and accompanying text.

${ }^{256}$ See supra notes $179-180$ and accompanying text.

${ }^{257}$ See supra Part IV.B.
} 
select patent cases as a litigating amicus who provides a disinterested analysis of the merits to vindicate the public interest (i.e., the fair, accurate, and timely adjudication of patent disputes) could fall within the scope of its existing activities (or be deemed a logical extension thereof) for which it could plausibly seek additional funding from Congress.

A related concern is whether a neutral litigant supplied by a government agency might unduly limit its involvement in a case in order to control expenses. In order for the neutral litigant to have a beneficial impact on the dynamics of a given case, it is not necessary for an agency to assign a large team of attorneys to a case; a single attorney may be sufficient. Indeed, in those ITC investigations with substantive OUII participation, only one ITC staff attorney is typically assigned, ${ }^{258}$ and that ITC staff attorney usually juggles several cases at once. In addition, it is not necessary for the agency attorney who acts as the neutral litigant to participate in every deposition, conduct full discovery on its own, or provide an exhaustive analysis of every motion filed by the parties. In discovery, for example, the agency attorney may participate in, or simply attend, the most important depositions and may elect to support certain motions to compel filed by the parties rather than propound discovery on its own. In motion practice, the neutral litigant's analysis need not "start from scratch," but rather would focus on comparing and contrasting the parties' arguments, and highlighting their respective strengths or weaknesses to the court. The ITC staff attorneys generally operate at the level of participation just described, ${ }^{259}$ and it has been sufficient to exert a collateral moderating effect on the parties' strategies. ${ }^{260}$ Apart from agency resource constraints, the assignment of a single agency attorney to the case is preferable to a team because the

258 See LYON \& PIEPMEIER, supra note 72, at 4 ("Although this process is currently changing, the OUII typically assigns $a$ staff attorney formally called the commission investigative attorney (the Staff) to each case." (emphasis added)).

${ }^{259}$ The ITC staff attorney, as a single individual, must necessarily prioritize the issues he seeks to substantively address in a given case. The Author has observed this occurring in practice.

${ }^{260}$ See supra Part III.A. 
former will focus on the most important issues as a matter of necessity, while the latter might unnecessarily increase the volume of litigation. An agency that seeks to implement a neutral litigant program for district court patent cases may find it useful to consult the ITC staff attorneys regarding their processes in order to design a workflow that would allow a single attorney to effectively participate in a complex patent case.

Impact on the Adversary System. Finally, some might object to the concept of a neutral litigant on the grounds that it could somehow undermine the adversary system. The proposal in this Article is not intended to change the adversarial nature of litigation, but rather to moderate its excesses. With the neutral litigant, the parties are not restricted from advancing their preferred theories of the case. Instead, the neutral litigant's participation induces the parties to perceive a strategic need to better prioritize the issues over which they will litigate-which is an activity that the parties should be doing anyway. And to the extent that this would be deemed "changing" the adversarial nature of litigation, it should be considered an improvement of the existing system. ${ }^{261}$

\section{Conclusion}

This Article illustrates how it may be possible to achieve standalone public interest representation in district court patent cases, and, at the same time, dampen the level of unnecessary contentiousness that impairs effective judicial decision-making, by using only a single entity: the neutral litigant. These dual benefits occur because the latter is a collateral effect arising from the

${ }^{261}$ See Schwarzer, supra note 36 , at 710 ("The incentives of the adversary system, for example, provide no effective check on costs. Unlike the British and Canadian legal systems in which the losing party routinely pays the winner's costs, including fees, the American system permits lawyers to impose costs on their opponents as long as the clients are willing to pay."); $c f$. Robert F. Peckham, A Judicial Response to the Cost of Litigation: Case Management, Two-Stage Discovery Planning and Alternative Dispute Resolution, 37 RUTGERS L. REV. 253, 265 (1985) ("[T] here is nothing sacrosanct about the adversarial system. It is a mere instrument by which to achieve the just resolution of disputes. If it can no longer fulfill that function effectively, it must be modified."). 
neutral litigant's acts in support of the former. Because the court is likely to give weight to the neutral litigant's disinterested analysis of the merits, each party will perceive a strategic need to "pick its battles" and cast its positions in the most credible light with the neutral litigant, whose support or opposition may affect the viability of a party's position before the court. Judges often make the mistake of treating overly contentious attorneys as squabbling children rather than as highly strategic entities. This Article shows that the conventional methods courts use to control attorney behavior, namely rules and sanctions, may not work nearly as well as changing the litigation environment so as to induce the attorneys to recalibrate their strategies. 
